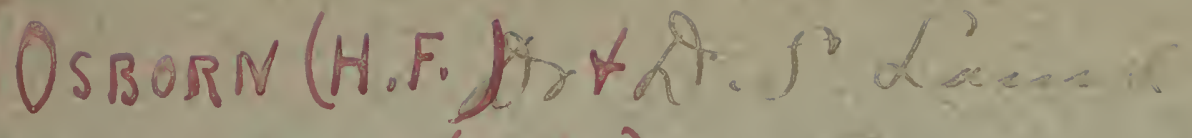 WORTMON $(J, L)$ )
}

Fossil Mammals of the Wahsatch and Wind River Beds. Collection of I89I.

By Henry Fatrfield Osborn and J. L. Wortman. With One Plate and Eighteen Figures in Text.

AUTHOR'S EDITION, extracted from BULLETIN OF THE

\section{Amevicax atuscum of axatural atistoxy,}

Vol. IV, No. I, Article XI, pp. 8I-I48.

Neze York, October 20, 1892. 



\section{THE DEPARTMENT OF MAMMALIAN PALAONTOLOGY.}

This department of the American Museum of Natural History was established in May, I89r. The purpose of the Trustees of the Museum is to procure a representative collection of the American fossil mammals from the successive geological horizons of the West for purposes of exhibition, study and publication. The staff consists of Prof. Henry F. OsBorn, of Columbia College, Curator, and of Dr. J. L. Wortman, assistant in Palæontology. Mr. Charles Earle and Mr. O. A. Peterson are also engaged as assistants, and Mr. RuDOLPH WERER as draughtsman.

The collections will be made readily accessible to students, and will be placed upon exhibition as rapidly as they can be put together and mounted. A list of such duplicate specimens as are available for purposes of exchange will be prepared. A series of casts of the best preserved types is also in preparation for exchange.

Preliminary descriptions of the new material in the collections will be published in the Museum Bulletins, and later, as fuller material is received, the Museum will publish Memoirs.

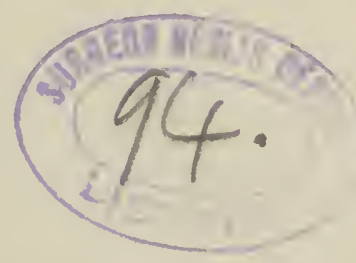



Article XI.-FOSSIL MAMMALS OF THE WAHSATCH AND WIND RIVER BEDS. COLIECTION OF i8gi.

By Henry Fairfield Osborn and J. L. Wortman.

With One Plate and Eighteen Figures in Text.

\section{INTRODUCTION.}

This paper is mainly given to a description of a collection made by Dr. Wortman in the Wahsatch (Big Horn) and lower Bridger (Wind River) beds during the summer of r89r. It includes the following special articles, each writer being responsible only for his own :

I.-Homologies and Nomenclature of the Mammalian Molar

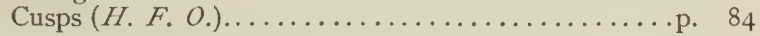

II.-The Classification of the Perissodactyla (H. F. O.)...p. 90

III.-The Ancestry of the Felidx $(J . L . W$.)........... 94

IV.-Taxonomy and Morphology of the Primates, Creodonts and Ungulates; I, Wahsatch; 2, Wind River (II.F. O.).p. IOI

V.-Geological and Geographical sketch of the Big Horn

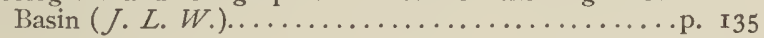

VI.-Narrative of the Expedition of $\mathrm{r} 89 \mathrm{I}(J . L . W.) \ldots \ldots$. $I 44$

Many new facts of great interest are brought out by the material in this collection, although Professor Cope has worked for years upon the Wahsatch fauna, with the assistance of Dr. Wortman in the field.

r. The lower jaw of Anaptomorphus homunculus is found to contain three premolars, instead of two, as in the type species A. comulus (p. го2).

2. The genus Palaonictis, hitherto found only in the Suessonian of France is also found in the American Wahsatch. The complete dentition and the facial region of the skull show that it is an extremely modified type, with only a single fully functional upper molar. It represents a family, the Palæonictidæ, including Ambloctomus (p. 106), and perhaps Patriofelis (p. 97), and is more like the Cats than any Creodont which has yet been found (pp. 95, 103). 
3. Additional remains of Oxyana show that the manus of this Creodont had a separate scapho-lunar and an os-centrale; the lumbar vertebræ have involuted zygapophyses; the pes is not cleft as Cope has described it. The incisors were $\frac{3}{3}$ (p. 109).

4. Among the Mesonychidæ is a small new form related to Dissacus of the Puerco, and a very large new species of Pachycena, by far the largest Creodont which has yet been found in the Wahsatch (p. II2).

5. The genus Anacodon, which has been doubtfully placed by Cope among the Condylarthra, is found to belong to the group of Creodonts with tubercular molars near Arctocyon. The upper and lower molar cusps are obtuse and covered with a great number of accessory tubercles; the premolars are reduced in number and pointed (p. I 15 ).

6. Complete limbs of Coryphodon show that the fore foot was digitigrade, as in the Elephant, while the hind foot was fully plantigrade, the whole plantar surface resting upon the ground as in the most primitive Ungulates (pp. I 20-122).

7. 'The complete dentition of Sl'stemodon, the earliest form of Tapir, is described (p. r24).

8. The complete limbs of Heptodon (Wind River), show that this animal belongs, with Helaletes of the Bridger, to a side line of small Perissodactyls with greatly reduced lateral toes. This family of Helaletidx extended from the lower Eocene into the Miocene; it is not ancestral to the Tapirs as Marsh supposed, nor is it (Heptodon) ancestral to the Hyrachyus series as Cope has suggested. The tooth structure is intermediate between the two. The foot structure is highly modified and aberrant both in the marked shortening of the lateral digits and in the long narrow terminal phalanges. Heptodon calciculus was a small, light limbed animal, somewhat of the dimensions of the Peccary (p. I29).

9. Many additional characters of Palaosyops borealis, the earliest known representative of this important Bridger genus, are noted (p. I32).

We pass by a large number of forms in the collection in which there is nothing to be added to the observations of Cope. 
DISTRIBUTION TABLE.

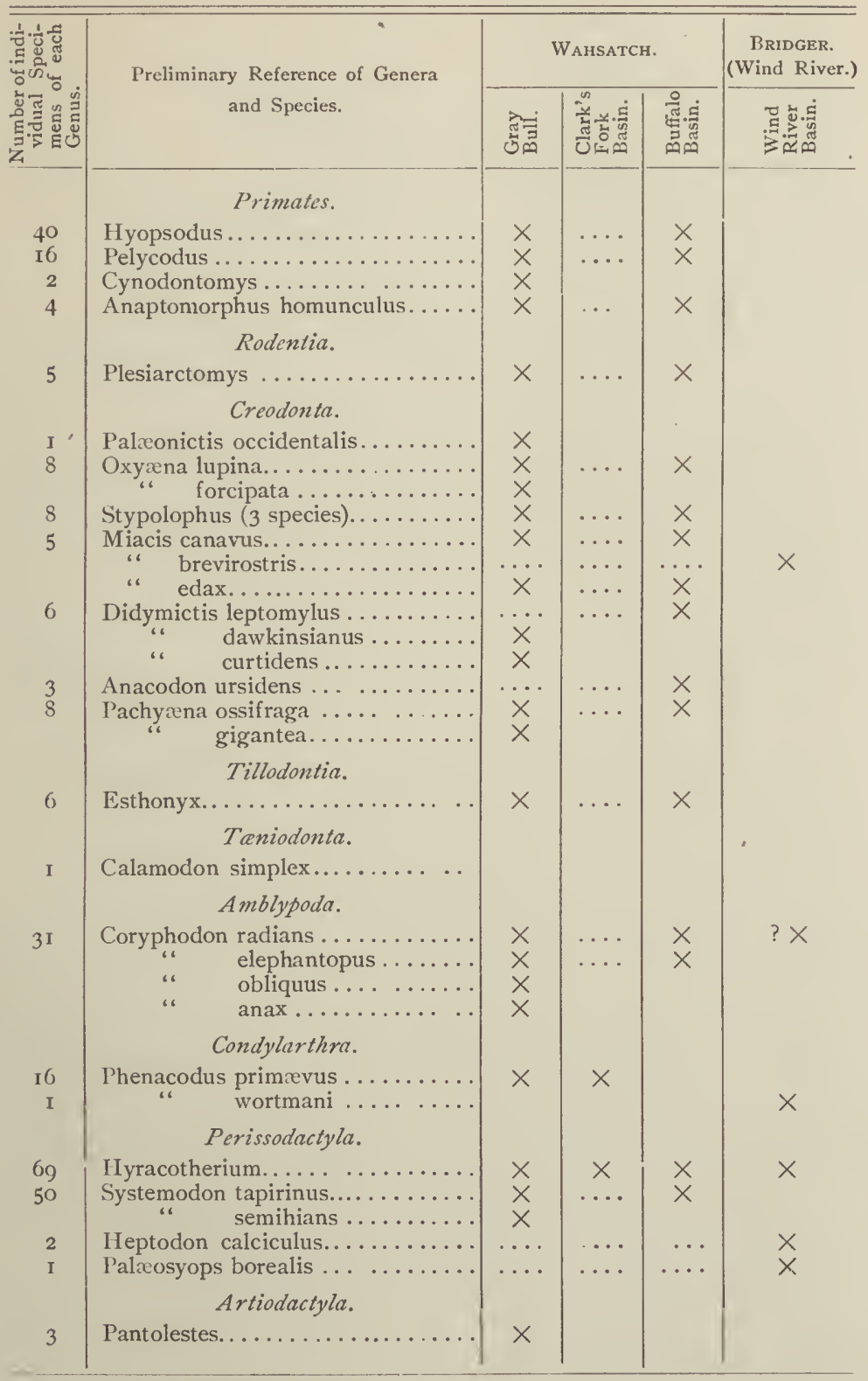


In the field great care was taken to observe and record the localities, and especially to note whether the fossils were from the lower, middle, or upper portions of the great Wahsatch beds of the Big Horn Basin, which are variously estimated at 2000 to 3000 feet in thickness. Of course this depth of rock represents a very long period of time in which the various species underwent considerable modification. We have therefore published in full Dr. Wortman's field notes upon the geology of the Big Horn and Wind River Basins, as well as geographical details, which will be of great service to collectors in the future (pp. 135-r44). We give $(p .83)$ a preliminary conspectus of the distribution of the species; this cannot be fully made out until all the species are determined by a comparison with Cope's types.

Before taking up the systematic description of the collection, we offer three introductory sections, treating of the structure of the molar teeth, the classification of the Perissodactyla, and the origin of the Felidæ.

\section{I.-Homologies and Nomenclature of the Mammalian Molar Cusps.}

In October, 1888 , a table of nomenclature for the cusps of the molar teeth of mammalia was published in the "American Naturalist." The terms were carefully chosen with reference to the gradual rise of these cusps from the single cone of the reptilian type, through the tritubercular to the sexitubercular stages. ${ }^{2}$ They have since been wholly or in part adopted by Cope, Scott, Lydekker, Schlosser, ${ }^{3}$ Flower, and lately by Rütimeyer. ${ }^{4}$ The tritubercular stem form has been recognized by Döderlein and Fleischmann, but these authors have employed various Greek symbols for the cusps. The latter has opposed the adoption of similar terms for the main cusps of the upper and lower molars, upon the ground that Cope and myself have mistaken the homolo-

\footnotetext{
1 Osborn, The Nomenclature of the Mammalian Molar Cusps, op. cit., p. 927.

${ }^{2}$ See also Evolution of Mammalian Molars to and from the Tritubercular Type, Am. Nat., December, 1888.

${ }^{3}$ Schlosser, Die Differenzierung des Säugethiergebisses, Biologisches Centralblatt, Juni, 1890

4 Die Eocäne Säugethier-Welt von Egerkingen, Zurich, r8gr.
} 
gies; this objection would be fatal to a uniform system of nomenclature for the upper and lower cusps if it could be sustained, but a comprehensive survey of the Mesozoic trituberculates, especially of the Amblotheriidæ and Spalacotheriidæ, leaves no doubt that the antero-external cusp in the lower molars and the antero-internal cusp in the upper molars of the mammalia are homologous with the reptilian cone and with each other; these cusps are invariably the most prominent, and are always styliform in primitive types; they always form the apices of the primitive crown; they persist in almost all mammals, while one or all of the later cusps may disappear.

This cardinal point established, it will be a great gain for palæontology and comparative odontology when the further truth is recognized that the possibilities of modification of type in the molars are limited, that essentially similar types of teeth are evolved independently over and over again, and that in course of what Schlosser has well termed 'modernization' we find such diverse orders as Primates, Ungulates, Insectivores, Marsupials, Rodents, all exhibiting the same laws of dental modification, and the same or similar ' secondary ' cusps, crests and peripheral styles.

Excepting in the Cetacea and Edentata, these modifications centre around the simple tritubercular crown, which seems to possess unlimited capacity of adaptation by the development of some parts and degeneration of others, by changes of form and.position, and by the addition of secondary cusps.

The first step is to distinguish and separate clearly the primary and secondary regions of the primitive crown, for originally they have absolutely different functions; the part first developed in both upper and lower molars is the anterior primitive triangle or trigen, which has a cutting or piercing function; out of its three cones all 'secodont' types of molars are evolved. The part next developed is the talon, or heel, which has a crushing or grinding function, and therefore plays a chief rôle in all 'bunodont' types. The first diagram exhibits the relations of these two portions of the crown in the upper and lower molars, and the six primary and secondary cusps which typically develop upon each (Fig. r).

We will not enter here into the well-understood transformation of this tuberculo-sectorial type into the sexitubercular bunodont 


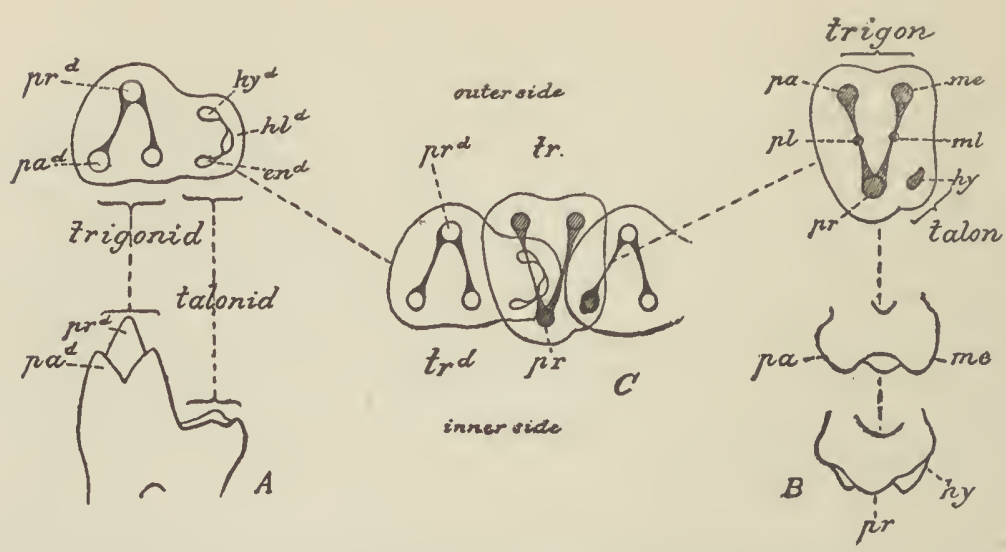

Fig. x. Diagram of the Tuberculo-Sectorial Stage of Mammalian Molars. A, The lower molar, crown and internal view. $B$, The upper molar, crown, internal and external views. $C$, Opposition of upper and lower molars.

type, seen typically in the upper and lower molars of the Puerco Protogonia, which is the least specialized ancestral bunodont form that has been discovered. We may lay emphasis upon the fact that the parent form of ungulate molar has six tubercles both above and below instead of six above and four below as formerly supposed.

It is important to remember, as an exception to the law of sexitubercular origin, that all the Amblypoda and all the Periptychidæ ${ }^{1}$

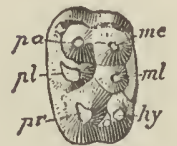

$\frac{3}{2}$

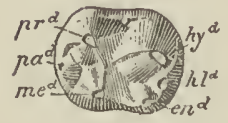

Fig. 2. The Primary Cusps of an Ungulate (Perissodactyl-Artiodactyl) Molar, Protogonia puercensis, and of the Condylarth, Phenacodus primavus. (For abbreviations, see table, page 9r.) (among the Condylarthra) developed their upper molars upon the trigonal basis, out of the three tubercles of the tritubercular crown, and without becoming sexitubercular, that is, without the addition of the hypocone or talon.

Now how shall we study the molar teeth of the early Ungulates, especially of the apparently

1 There are considerable grounds for removing the Periptychidæ from the Condylarthra to the Amblypoda.-O. 
similar primitive forms of Perissodactyls, which are so difficult to distinguish? 'The following steps must be taken :

First.-Locate each of the six primary and secondary cusps, as far as they are present.

Second.-Note the form of each, whether rounded (bunoid), crested (lophoid), or crescentic (selenoid).

Third.-Note the position of each upon the crown with relation to the other cusps.

Fourth.-Note the relative size or development of each.

Fifth.-Note the relative development of the cingulum, in different parts of the contour.

Sixth.-Note the presence of one or more peripheral secondary cusps, which develop from the cingulum, or external borders of the crown.

Finally.-If crests are formed or forming, note the points at which the transverse crests unite with the external cusps (paracone and metacone, parastyle and mesostyle).

These differential features, it will be observed, follow the progressive order of evolution in the molar crowns, for in 'modernization' we see, first, a degeneration of one or more of the primary cusps, then a remodelling of the form of each cusp which may affect the twelve upper and lower cusps very differently: for example, in such an ancient type as Meniscotherium we find one bunoid, two lophoid, and three selenoid cusps in each of the upper molars. Third, the cusps begin to shift their positions upon the crown. Fourth, they begin to develop unequally. Fifth, the cingulum, which is primitively a complete peripheral band, begins to disappear at certain points. Sixth, one or more peripheral cusps grow up from the cingulum or upon the sides of the main cusps. Finally, as the crests develop, the unequal development of the cusps causes the transverse crests to unite at different points with the external crest.

We find that if such analysis be applied to the elements of the molar teeth we derive an absolutely infallible means of distin- 
guishing different lines of descent, for the above are the main features of divergent evolution.

The primitive horse, tapir, rhinoceros and titanothere all stand apart and cannot be confused; each have their clear differentia. To check the possibility of being misled by parallelism in molar form, we should next observe the dental series as a whole, the proportionate development of different members of the seriesthe metatrophism ; this often furnishes the final proof or disproof of relationship, so far at least as can be derived from the dentition alone.

The above method of analysis is the outgrowth of an extremely careful study and comparison of all the early Condylarthra and Perissodactyla, and it has been found necessary to exercise the closest scrutiny to distinguish these early stages of divergence.

Now to turn to the subject of nomenclature, the system of terms was originally based upon the actual homologies of the primary elements of the trigon and trigonid, but in extending it to the other parts of the crown and to the secondary cusps it was found that we must apply similar terms to some of the later elements in the upper and lower teeth, which are merely analogous to each other (performing a similar function, occupying a similar position, and developing at about the same period), otherwise the terms soon multiply so as to become a burden rather than a convenience.

As far as possible, therefore, the same prefixes are retained for the secondary parts of the molars as for the primary; thus the anterior transverse crest of the upper molars is called the proto$l o p h$, as it is invariably developed by the union of the protocone, protoconule and paracone or parastyle, never from the metacone. The anterior transverse crest of the lower molars is termed the metalophid because it is always developed from the metaconid or metastyle, and protoconid, never from the paraconid ; the posterior transverse crest of the lower molars is termed the hypolophid, because it is mainly formed by the hypoconid and entoconid, never from the metaconid or paraconid. The external crest of the upper molars is composed of so many cusps that it requires a distinct prefix, but is readily remembered as the ectoloph. So with the peripheral cusps, one or more of which are developed in 
all Ungulates, and are especially numerous in molars of the Equidæ; to these the terminal -style is applied in lieu of the English term 'pillar' proposed by Huxley-we can readily locate
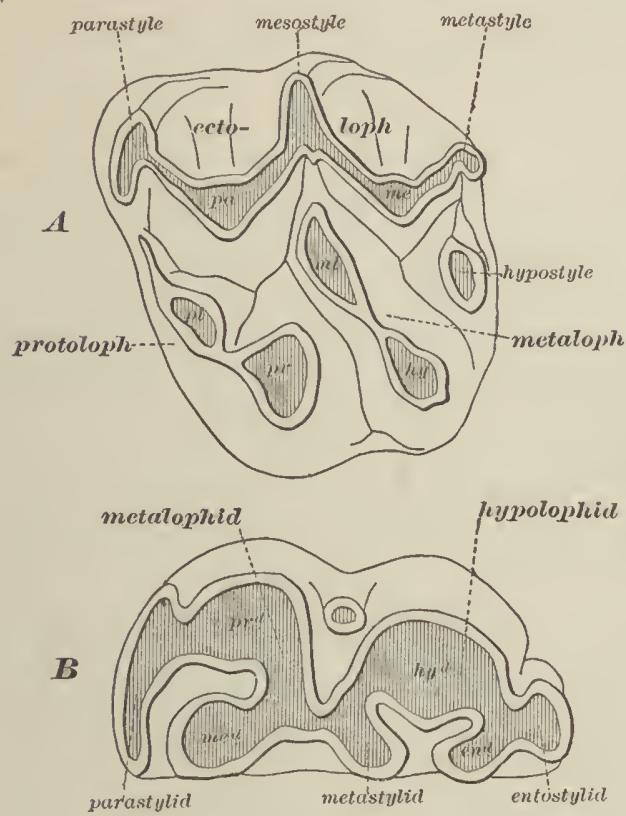

Fig. 3. The Secondary Cusps of an Ungulate Molar. $A$, Anchitherium, upper. $B$, Merychippus, lower. The Primary Cusps are indicated by abbreviations. the parastyle as the antero-external buttress which is develop)ed near the paracone, the mesostyle as developed on the outer wall between the paracone and metacone. Similarly, in the lower molars, we find in several lines of Ungulates, but again most conspicuously in the Equidx, that the metaconid and entoconid are reinforced by little cusps which grow up behind them $(a, a$ and $b, b$, Rütimeyer); these may be termed respectively the metastylid and entostylid, while the pillar arising secondarily in the primitive position of the paraconid may be termed the parastylid.

The principles upon which this terminology is based are therefore very simple.

I. The termination -cone is given to the main primary or central cusps, and -conule to all intermediate cusps.

2. The termination -style is proposed for the peripheral cusps arising mainly from the cingulum.

3. The termination-loph is applied to the crests.

4. The seven prefixes are based upon the succession and position of the elements in the primitive evolution of the crown, viz. : 
proto-, para-, meta-, hypo-, ento-, ecto-, meso-. The prefixes are first applied to the cones; then to the styles, according to their proximity to the cones; then to the crests, according to the cones which mainly compose them.

5. Homologous and analogous elements in the upper and lower jaws are given similar terms, but distinguished arbitrarily by the terminal $-i d$.

Upon the opposite page are given the terms formerly employed by French, German and English authors for the teeth of the Ungulates before their common tritubercular origin had been discovered by Cope. In his 'Enchainements du Monde Animal' Professor Gaudry, as far back as 1878 , worked out most clearly the homologies of the molar elements in the Ungulates from the sexitubercular-quadritubercular stage onwards; the valuable earlier studies of Ruitimeyer ${ }^{1}$ are well known. But now that the ungulate molar has been found to converge to the unguiculate molar type, and both are found to contain the same elements, and to spring from the same mesozoic source, it is important to unify our methods of description by adopting a set of terms which refer back to the primitive form and position in place of those which were based upon the comparatively modern form and position.

\section{II.-The Classification of the Perissodactyla.}

In this paper a departure from the current system of classification of the fossil Ungulates is adopted-the early members of each of the great families of Perissodactyla are placed in subfamilies under the most recent family names, Equidæ, Rhinocerotidæ, 'Titanotheriidæ, etc.

The main desiderata of classification are : first, clearness in the expression of phyletic relationships; and second, convenience. Neither is attained when we place the well-determined ancestors of existing or of recently extinct families in separate families founded upon the similar transition characters of ancestral types. We have elsewhere ${ }^{2}$ protested against the principles of family

\footnotetext{
1 Beiträge zur Kenntniss der fossilen l'ferde, Berlin, 1863.

${ }^{2}$ See Osborn, The Mammalia of the Uinta Formation, pp. 550, 536 (footnotes).
} 
No. I.] Osborn and Wortman on Fossil Mammals.

9I

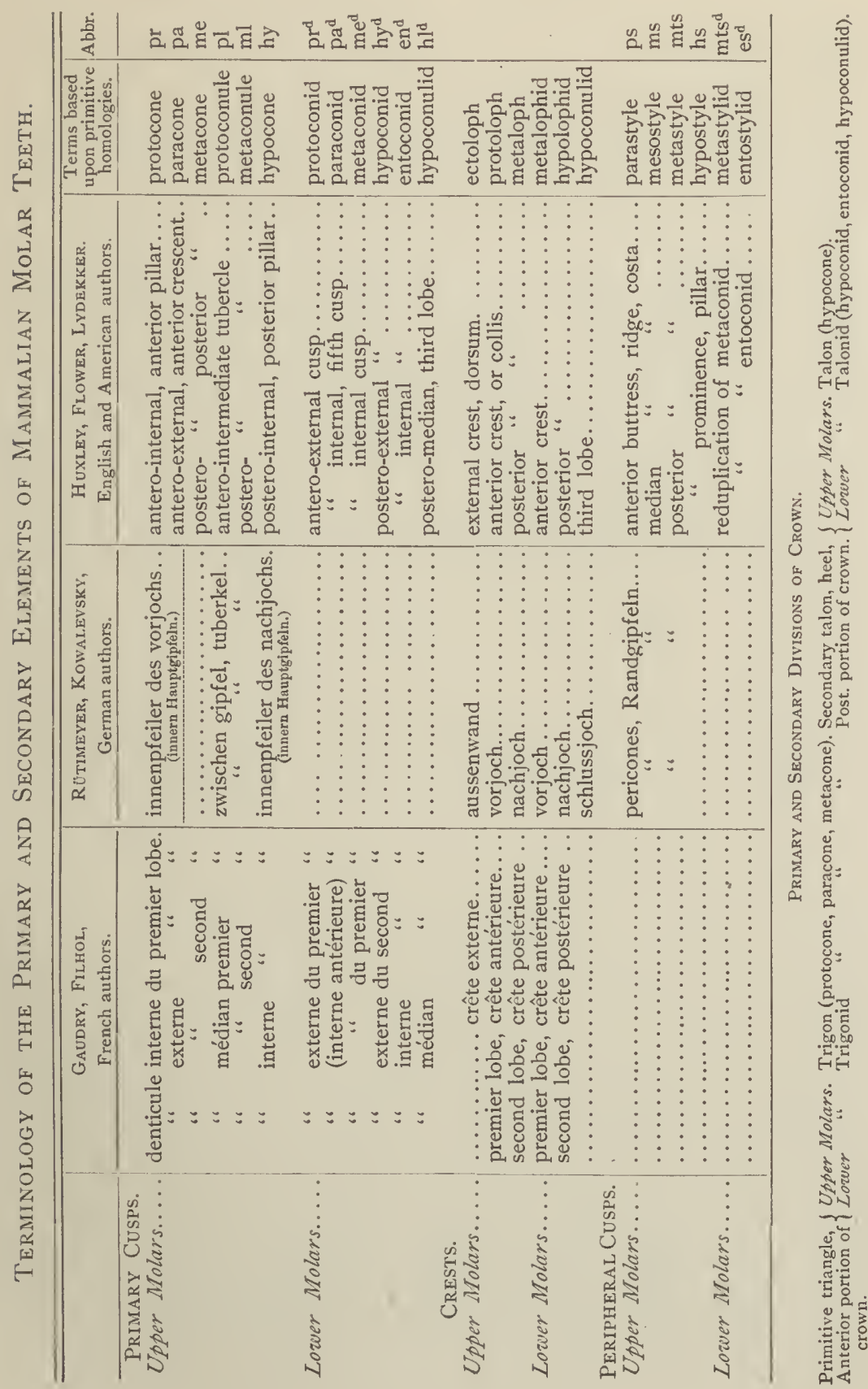


division adopted by Cope and Lydekker, especially against the meaningless term Lophiodontida. Why not place an ancestral horse among the Equidæ, instead of terming it a 'lophiodont,' especially when we are at present ignorant what the Lophiodontidæ were? Formerly there may have been some ground for the use of the latter family in a vague comprehensive sense to embrace Perissodactyls in a common stage of premolar evolution (i.e., premolars simpler than molars), but this ground has been wholly removed by the discovery that even in the Wahsatch period the horses, tapirs, titanotheres, hyracodonts, rhinoceroses and other series were clearly separated from each other, either by wellmarked structural characters in the teeth and feet or by welldefined developmental tendencies. If we embrace primitive horses, tapirs and rhinoceroses in the Lophiodontidæ on the ground that the premolars in these animals are unlike the molars, we practically raise this family to the rank of an order, and, moreover, find it impossible to define it, for we thus confuse a merely similar stage of evolution with a similarity of descent.

Schlosser, with whose ideas about classification we thoroughly agree, has taken the other extreme, and placed all the extinct forms under the recent families $;^{1}$ this is a far clearer method, but it is even preferable to group earlier and collateral forms under subfamily names.

By such an arrangement of the Perissodactyla we pass from one extreme to the other in the types of transformation of the molars. We give chief weight to tooth structure, as for example in separating the Helaletes from the Hyrachyus series, and secondly to foot structure, as for example in the doubtful separation of the Palaplotherium (monodactyl tendency) from the Palaotherium (typical tridactyl) series. The position of the Amynodontidæ ${ }^{2}$ will remain somewhat uncertain until we ascertain the foot structure; the tooth structure is intermediate between that of Hyrachyus and Rhinocerus. The position of the Lophiodontidæ is also uncertain; the Lophiodons are not, as generally supposed, related to the Tapirs, and until we ascertain the skull and foot structure

${ }^{1}$ Beiträge zur Stammesgeschichte der Hufthiere.... Morph. Jahrbuch, Bd. XII.

2 This family was defined by Osborn, Mammalia of the Uinta Formation, p. 507. 


\begin{tabular}{|c|c|c|c|c|c|}
\hline 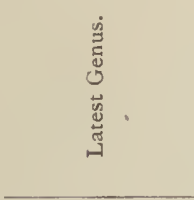 & 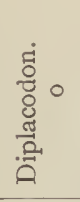 & 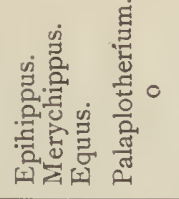 & 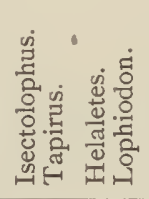 & 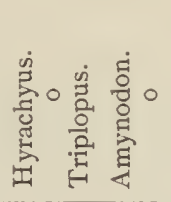 & 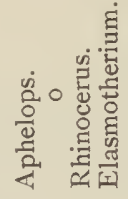 \\
\hline 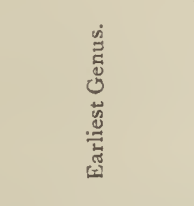 & 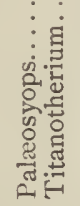 & 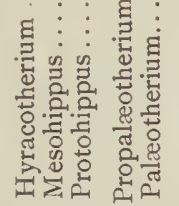 & 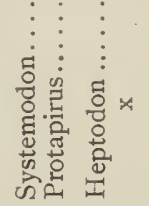 & 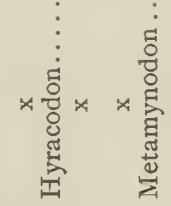 & 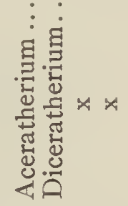 \\
\hline 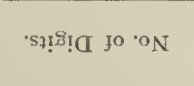 & $\begin{array}{l}0 \\
1 \\
1 \\
1\end{array}$ & $m m \tilde{1}$ & 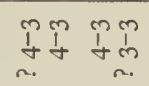 & 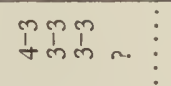 & 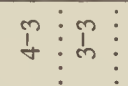 \\
\hline 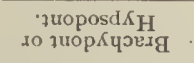 & $\dot{a}=$ & $=: \dot{\overrightarrow{\mid r}}$ & $:=:=$ & $::=:=$ & $=:=\dot{\Delta}$ \\
\hline 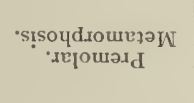 & $\begin{array}{l}\text { घं घं } \\
\text { v \|! } \\
\dot{2}\end{array}$ & 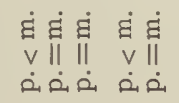 & 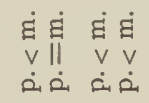 & 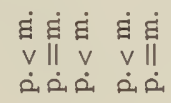 & 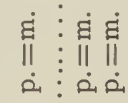 \\
\hline 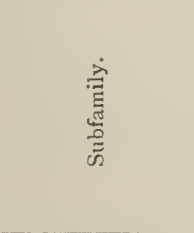 & 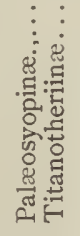 & 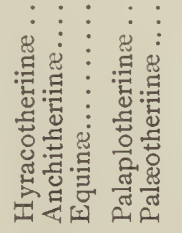 & 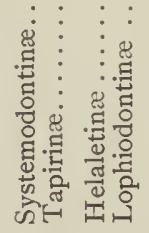 & 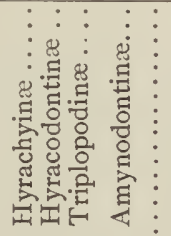 & 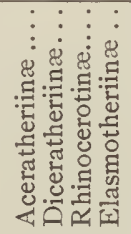 \\
\hline 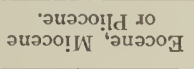 & घi & 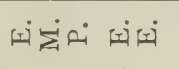 & 玨玄 任 & 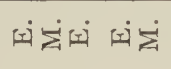 & 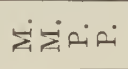 \\
\hline \multirow[t]{2}{*}{ 离 } & 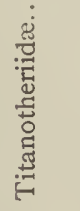 & 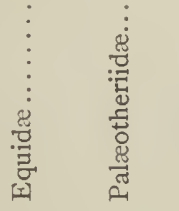 & 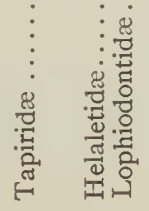 & 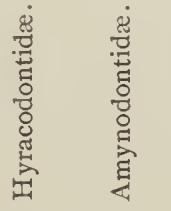 & 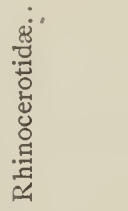 \\
\hline & 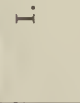 & $\underbrace{ઘ \quad \Xi}$ & $\underset{m}{i s}$ & $\underbrace{\stackrel{\Xi}{5}}$ & 远 \\
\hline 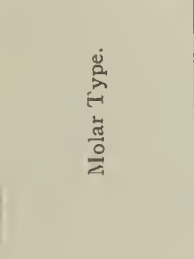 & 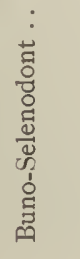 & 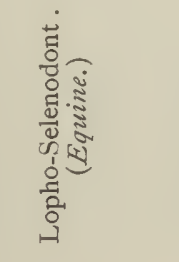 & 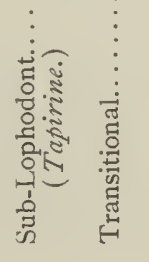 & 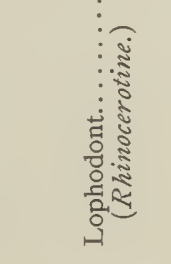 & \\
\hline
\end{tabular}


they remain problentatical; the nearest relatives are the Helaletidæ.

'The sub-families of Rhinocerotidæ are equivalent to what Lydekker has called "Aceratherine Group," "Diceratherine Group," etc. As several of these groups contain more than one genus, it appears convenient to raise them to the rank of subfamilies. It is evident that the Systemodontinæ and Tapirinæ are very similar in tooth structure, and that their relationship will turn upon the structure of the feet.

\section{III.-The Ancestry of the Felide.}

The Mrocene Cats.-So far there appears to be entire unanimity of opinion in favor of the proposition that the Miocene Nimravidæ stand in direct ancestral relation to the true cats, and while they exhibit a number of primitive characters yet, even at the beginning of the Miocene epoch, they had become sufficiently specialized to present many of the more important characters which now distinguish the modern Felidæ.

There can be little doubt but that the Nimravidæ present many resemblances to the Viverrida, chiefly through the living genus Cryptoprocta, which Mivart refers to this latter family. These resemblances have influenced Scott to believe that the two families have had a common ancestry. ${ }^{1}$ Whether this proposition is true or not future discovery must decide.

Some of the more striking characters in which the Nimravidæe resemble the cats most, are seen in the short muzzle in comparison with the skull, the wide zygomata, the divergence of the tooth lines posteriorly, together with the reduction in the molar and premolar dentition. Other characters of importance are the straight transverse line in which the lower incisors are placed, together with those derived from the lower jaw.

The principal characters in which they differ from the true cats are to be found in the foramina at the base of the skull, the possession generally of a second lower molar, the greater size and less internal position of the single upper molar, the presence of a distinct talon, and the frequent appearance of an internal 
tubercle upon the lower sectorial. The superior sectorial is, moreover, less perfect in generally lacking the third lobe or anterior cutting blade, while the premolar formula as a rule is less reduced. To these must be added other characters derived from the skeleton (Fig. $5, B$ ).

It is to be borne in mind that these generalized Nimravine forms made their appearance in the oldest Miocene deposits of this country and probably at an earlier date in Europe, if we consider the Phosphorites of France to belong to the upper Eocene, as is done by some palæontologists, so that their ancestry must be sought for in formations older than this horizon. The fact that no representatives of the Viverrida have yet been found in this country militates against the view of their origin in America, at least, from this source, although of course it is not impossible that migration may have taken place. 'The same argument applies to the Creodont Miacis, which has thus far been found only in the American Eocene.

Relations of THE CReodonts to The Felid has maintained that the feline phylum has been derived independently from the Creodonts. ${ }^{1} \quad$ Cope formerly held a similar view, ${ }^{2}$ deriving the Felidæ directly from Oxyana. Later he has changed his mind and now considers all the Carnivora as direct decendants of the Miacidæ. ${ }^{3} \quad$ Scott has expressed a similar view ${ }^{4}$ and derives the Nimravidæ, which in turn gave rise to the Felidæ, directly from the Miacidæ.

With reference to the direct origin of the Nimravidæ from any known Creodont, the evidence heretofore has, however, been so meagre as to compel both Cope and Scott to reject the hypothesis as altogether conjectural.

Scott, in his excellent memoir already cited, observes: "No known group of Creodonts can be selected as having any close relations to the cats. The Oxyænas, it is true, do exhibit surprising analogies with this recent family, but the analogy is con-

1 Ueber die Beziehungen ausgestorbenen Säugetierfaunen und ihr Verhaltnisse zur Säugetierfauna der Gegenwart. Biologisches Centralblatt, Bd. VIII.

2 Tertiary Vertebrata, p. $26_{4}$.

3 The Creodonta. American Naturalist, March, $x 884$, p. $26 r$.

4 Notes on the Osteology and Systematic Position of Dinictis felina, Leidy. Proc. Acad. Nat. Sci., Phila., July 30, 1889, p. 242. 
fined to the teeth, and is only superficial, as the teeth, which in the two groups look so much alike, are not homologous, and are developed in quite a different way." While this objection holds true of Oxyana it does not necessarily apply to all the Creodonta, and if it can be shown that there is an Eocene genus of Creodonts, which fulfills the necessary requirements, then in our judgment it becomes equally, if not more probable that the ancestry of the Nimravidæ is to be referred to it, rather than to any group which has not been shown as yet to precede it in time.

Judging from the tooth and skull structure of the Nimravidæ, what characters would one be led to look for in their ancestors? We would say that in the upper jaw there should be a short muzzle, well-developed canines, a wide palate posteriorly, rapidly diverging tooth lines, marked tendency to molar reduction, and a large infraorbital foramen. In the lower jaw there should be a moderately deep ramus, straight upon its lower border, a flattened, truncated symphysis, an inferior dental foramen placed well below the tooth line, a distinct scroll-like condylar facet and a reduced second true molar.

Paleonictis and the Felide.-These conditions we have fulfilled completely in the genus Palconictis; the muzzle is short and the infraorbital foramen large, reminding one at once of Dinictis. The palate is relatively short and broad posteriorly; the second upper molar ( $m 2$ ), although present, is reduced quite as much as is the first true molar of the existing cats, having but a single root and a degenerate crown. The fourth superior premolar, while it does not display the perfect blades of the welldeveloped sectorial, nevertheless possesses the required primitive elements from which this tooth has been developed. 'The blades of the inferior sectorial $\left(p r^{d}\right.$ and $\left.p a^{d}\right)$ produce a distinct 'shear' against the posterior and outer median cusps, as is demonstrated by the increased wear at this point. (See Fig. $5 F$, and Plate IV.)

In the lower jaw we note the deep ramus with the comparatively straight inferior border; the inferior dental foramen is situated well below the tooth line, the symphyseal region is relatively broad and truncated, and the condylar facet has the distinctively scroll-like pattern seen in the cats. The second true molar is reduced in size, smaller than the sectorial, while the 
sectorial itself has a relatively large talon and internal tubercle. The two blades of the sectorial are comparatively little developed, and they occupy a position at a considerable angle to the long axis of the jaw. The internal and external tubercles of the anterior triangle form a subsidiary blade which shears against the anterior edge of the internal tubercle of the first upper true molar, as is demonstrated by the wear exhibited in this situation.

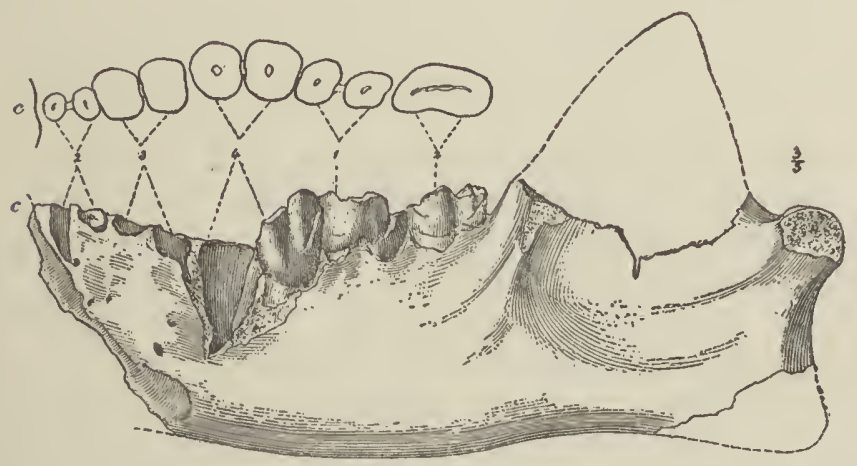

Fig. 4. Patriofelis ulta, type specimen, National Museum. External view of left lower ramus. Alveoli of teeth from above. Three-fifths natural size.

\section{Patriofelis ulta Leidy.}

As will be noted, Palconictis has been found thus far only in the lower Eocene (Wahsatch and Suessonian), and before we are able to establish a connection with the Miocene forms it is necessary to know something of its successors in the Wind River and Bridger formations which lie intermediate. The only specimens known to us from the Bridger which can be related to Palconictis are the type of Patriofelis Leidy, and an undescribed jaw in the Princeton Collection which Professor Scott has kindly placed at our disposal.

We may first consider the former. As shown in Fig. 4, and described by Leidy, the inferior dentition of $P$. ulta is probably $\mathrm{p}=3, \mathrm{~m}=2$. 'The fourth premolar is the best preserved tooth; it is relatively larger than the first true molar, judging by the proportionate measurement of the fangs. The outer face of the crown and the characters of the deuterocone, or posterior basal [September, 18q2.] 
cusp, are closely similar to the corresponding parts in Palaonictis and Ambloctonus. The first true molar of the Patriofelis type is badly broken. The second true molar is proportionately larger than in Palconictis.

\section{? Patriofelis leidyanus, sp. nov.}

The Princeton specimen (Fig. 5, C, ) may be provisionally referred to the same genus, and distinguished as $P$. leidyanus. 'The specific character is that the fourth lower premolar is smaller than the first true molar. It carries the third and fourth premolars together with the first molar or sectorial. It also bears distinct traces of the canine alveolus, which serves to demonstrate that the complete jaw contained but three premolars, the first of which was probably small and single rooted. The length of the tooth line indicates that the jaw was short, resembling in this respect some of the modern cats. The principal interest, however, centers in the first true molar, or, sectorial, in which we observe all the elements of the corresponding tooth in the most generalized forms of the Nimravida, but also just such an advance over the sectorial of Palaonictis as the sectorial of Felis advances beyond that of Dinictis. In this specimen we note that the two blades are much better developed than in Palaonictis, and occupy a position almost if not quite parallel with the long axis of the jaw. The internal tubercle and talon are much reduced. The posterior faces of the external and internal tubercles are rounded, not flattened as in Palaonictis, and there is no evidence of a secondary shear between this part of the tooth and the anterior edge of the internal lobe of the first upper true molar, which would have undoubtedly been the case if this part of the upper tooth had been well developed.

'This evidence leads indirectly to the supposition that the first upper molar was considerably reduced, which in turn would seem to justify the inference that the last upper molar had completely disappeared. While this view is of course inferential, it is nevertheless strongly suggested by what we know of other forms, as, for example, Amblyctonus. 'The points of wear in one series and a knowledge of the lobes and cusps which produce it 

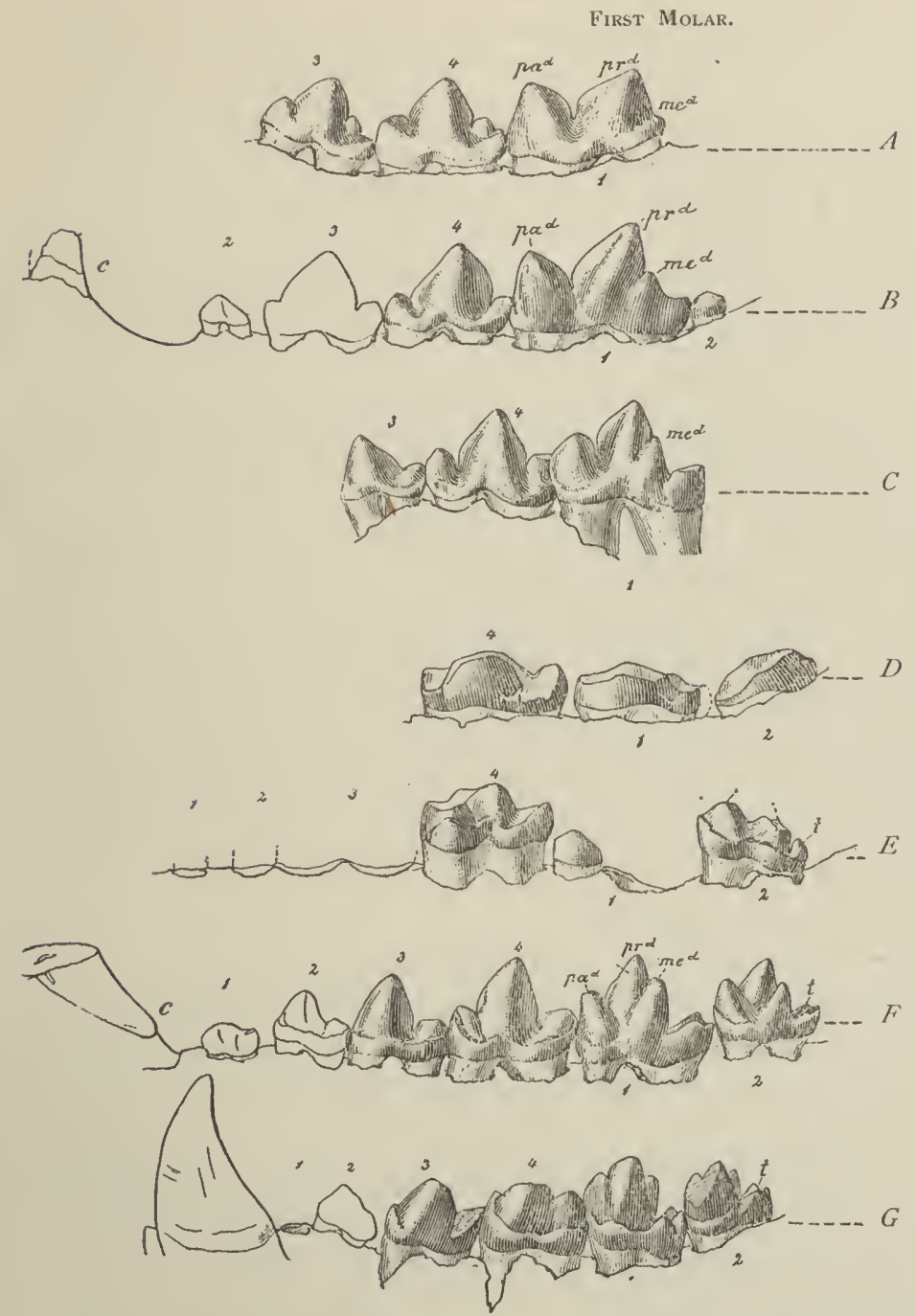

Fig. 5. Series of types showing (1) the evolution of the Sectorial Molar; (a) the reduction of the Talon, $t$, of the second molar in the P'alaonictida. All figures natural size.
A. Felis concolor
(inner view).
E. Ambloctonus sinosus
(inner view).
B. Dinictis felina
"
F. Paleonictis occidental is
(outer view).
$C$. ? Patriofelis leidyanus "
D. Ambloctonus (onter view).
$G$. Palæonictis gigantea 
in the other, is of the utmost importance in determining the relationship between the upper and lower teeth. This is of all the greater moment when we have to deal with a rapidly degenerating series of teeth, as we do in the present instance. When the complete dentition of this interesting form is known, we are induced to predict from the evidence already cited that it will be found to have but a single upper true molar much better developed than in any of the Nimravidæ at present known, that there will be found to be two true molars in the lower jaw, with the last one intermediate between the conditions now exhibited by Dinictis and Palaonictis, that the premolars will be three in the lower and three or four in the upper jaw, and that altogether it will display marked affinities in the direction of the Nimravidæ.

Conclusions.-The evidence which we here present in favor of the derivation of the cats from the Palæonictidæ is based solely upon a consideration of the teeth and of the form, so far as we can judge, of the jaws, but it may transpire that when the skeleton of Palconictis is discovered there will be difficulties presented which will invalidate this evidence; and before we are in possession of such facts any final judgment in the matter must be regarded as premature. However, we have deemed the matter of sufficient importance to discuss it thus fully. 'The evidence may be summed up as follows :

In favor of this genetic relationship :

I. Palconictis presents the same mode of dental reduction as the Nimravidæ and Felidæ, namely : rapid loss of the posterior pair of upper and lower molars and of the anterior premolars.

2. It presents the same sectorials as the Felidx, namely: the fourth upper premolar and first lower molar.

3. It presents the feline conformation of the skull.

Against this relationship :

I. Palconictis and Patriofelis (ulta) show an enlargement of the fourth lower premolar not observed in the Felidæ.

2. The evidence rests solely upon the teeth, as the foot structure and skeleton of Palaonictis is unknown. 
A conservative conclusion based upon our present evidence is that the Palconictida were a family of Creodonts from which the Felide may have sprung. No other known Creodonts present so many points of resemblance with the cats, or the possibilities of such derivation.

The mode of dental reduction, the homologies of the lower molar cusps, showing the rise of the sectorial by the development of the paraconid and protoconid, are beautifully shown in the above series of figures. (Fig. 5, $A-G$.)

\section{IV.-Taxonomy and Morphology of the Primates, Creodonts and Ungulates.}

\section{I.-Wahsatch Fauna.}

\section{Order PRIMATES.}

The collection is very rich in the Lower Eocene Monkeys, containing four specimens of Anaptomorphus, forty of Hyopsodus, sixteen of Pelycodus, two of Cynodontomys, and several specimens which cannot be determined.

Classification of the Fossil Primates. - It seems probable that the Anaptomorphidæ belong to the Lemuroidea, although this reference rests merely upon the external position of the lachrymal foramenin the type skull of Anaptomorphus homunculus, and we have not at present any means of determining whether the inferior caniniform tooth is a true canine, as in the Anthropoidea, or is a modified first lower premolar as in the typical Lemuroidea.

The other Eocene Monkeys, such as the Adapidæ, the Notharctidæ (= Limnotheridæ, Marsh), and the Microsyopsidæ have also been usually placed in the Lemuroidea, but there is absolutely no ground for this reference; while there are, on the other hand, many reasons to believe that they are primitive Anthropoidea, and that they bear somewhat the same relation to the modern Anthropoidea that the Eocene Perissodactyla bear to the modern 
Perissodactyla. At least, there are no means of separating them from this suborder.

Schlosser was the furst to unite the Eocene Monkeys of Europe in the 'Anthropomorphæ,' but he has inconsistently separated the American Monkeys as 'Pseudo-lemuroidea,' a division which if valid is preoccupied by the 'Mesodonta' which Cope has abandoned.

\section{Sub-order LEMUROIDEA.}

\section{Family ANAPTOMORPHID $\approx$ Cope.}

This family is distinguished by its extremely reduced dentition; the premolars are unlike the molars, and are $3^{-2}$ in number; there are but two lower incisors, and apparently a true canine; the upper molars are tritubercular; the lower molars are quinquetubercular or quadritubercular.

A comparison of Leidy's type of Omomys, from the Middle Eocene (Bridger), with Cope's specimens and those in the American Museum, shows that it probably belongs in this family, although a small second premolar persists as in the Wahsatch species of Anaptomorphus (A. homunculus), and the chin is more elongate and less rounded than in $A$. amulus from the Bridger. In every detail of dental structure, excepting the above, Omomys closely resembles Anaptomorphus.

\section{Genus Anaptomorphus Cope.}

It will be remembered that Cope's type ( $A$. amulus) of this genus is a lower jaw with the formula $\mathrm{I}_{2}, \mathrm{C}_{\overline{1}}, \mathrm{P}_{\overline{2}}, \mathrm{M}_{\overline{3}} . \mathrm{He}$ subsequently referred to the same genus the species $A$. homunculus, founded upon a skull (without the jaws) from the Wahsatch. It is interesting to record the discovery of a specimen from the Wahsatch in which a nearly complete lower jaw is associated with upper teeth identical with those of $A$. homunculus.

\section{Anaptomorphus homunculus Cope.}

The best specimen (No. 4r) consists of portions of the two maxilla containing two premolars and three molars, and of a lower jaw containing the corresponding teeth. 
As might have been anticipated, the inferior true molars are in a slightly earlier stage of evolution than those in the Bridger species. Cope has described the molars of A. cmulus as "quad-

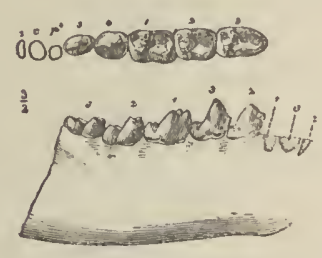

Fig. 6. Anaptomorphus homunculus; external view of lower jaw and crown view of teeth. I 1 . natural size.

$A$. cemulus, but the internal cuspule is not visible upon the fourth A more important primitive character is indicated by a very small alveolus for the root of a second premolar upon the outer side of the jaw, so that the formula of this species should probably be written : Premolars, $\frac{? 2}{3}$. Molars, $\frac{3}{3}=A$. homunculus. We cannot determine whether there is also a trace of the second premolar in the maxilla. Three other specimens (Nos. 42, 43, 44) may be similarly referred.

\section{Order CREODONTA Cope.}

This order is represented in the collection by specimens belonging to all the known Wahsatch families, namely the new family Palæonictidæ, the Oxyænidæ, the Miacidæ, the Proviverridæ, the Mesonychidæ and the Arctocyonidæ.

\section{Family PAL $\mathbb{E O N I C T I D \# . ~}$}

The material at our disposal indicates that Palcenictis belongs to a distinct family of Creodonts. Cope has in fact placed it with Ambloctonus in the Ambloctonidæ, although he misinterpreted the dental formula of Ambloctonus, owing to the extremely fragmentary condition of the type.

It is important to distinguish these forms clearly from the Oxyænidæ, with which they present a superficial resemblance. 
IO4 Bulletin American Museum of Natural History. [Vol. IV,

\section{Palconictide.}

Face short. Fourth upper premolar and first lower molar, only, developing into sectorial. Dental reduction the same as in Felidxe (i.e., m. $\frac{2}{2}$ and $\frac{2}{3}$ disappear).

\section{Oxycinide.}

Face long. Fourth upper premolar and first upper molar, first and second lower molars developing into sectorials. Dental reduction unlike that in Felidx (i.e., m. $\frac{3}{3}$ disappear).

The Palæonictidæ are distinguished readily from the Proviverridæ (to which the contemporary Stypolophus belongs) by the extreme reduction of the upper and lower true molars.

\section{Family Palaonictida.}

Palconictis: I $\frac{3}{3}, \mathrm{C} \frac{1}{1}, \mathrm{P} \frac{4}{4}, \mathrm{M} \frac{2}{2}$. Second upper molar very small. Second lower molar with well-developed talon. First lower molar tuberculo-sectorial. Ambloctonus: I ?, C $\frac{1}{1}, \mathrm{P} \frac{4}{4}, \mathrm{M} \frac{1}{2}$. Second upper molar absent. Second lower molar with talon rudimentary or wanting.

Patriofelis : I ?, C $\frac{1}{1}, \mathrm{P}_{\frac{1}{3}}, \mathrm{M} \frac{\frac{1}{2}}{2}$. (First lower molar sub-sectorial.)

\section{Genus Palæonictis De Blainville.}

P. gigantea De Blainville. Talon of second lower molar long, with three cusps. (Suessonian of France.)

$P$. occidentalis, sp. nov. Talon of second lower molar short, with a single cusp. (Wahsatch of America.)

\section{Genus Ambloctonus Cope.}

$A$. sinosus Cope. Talon of second lower molar wanting, or reduced to a spur. (Wahsatch.)

\section{Genus Patriofelis Leidy.}

$P$. ulta LEIDY. Fourth lower premolar larger than first molar.

$P$. leidyanus, sp. nov. Fourth lower premolar smaller than first molar.

\section{Palæonictis occidentalis, sp. nov.}

Plate IV.

It is important to establish at the outset the generic status of the type specimen. Its reference to Palconictis rests upon the absolute similarity of detail in the structure of the lower teeth with those of De Blainville's types, which are two fragmentary lower jaws containing the third and fourth premolars and two molars. The specific distinction of $P$. occidentalis is the degeneration of the talon of the second lower molar. Ambloctonus is very close to Palaonictis, if not actually identical, but it may for the present be distinguished by the presence of but one upper molar. (See Fig. 5, D,E, $F, G$. Also Fig. 8.) 

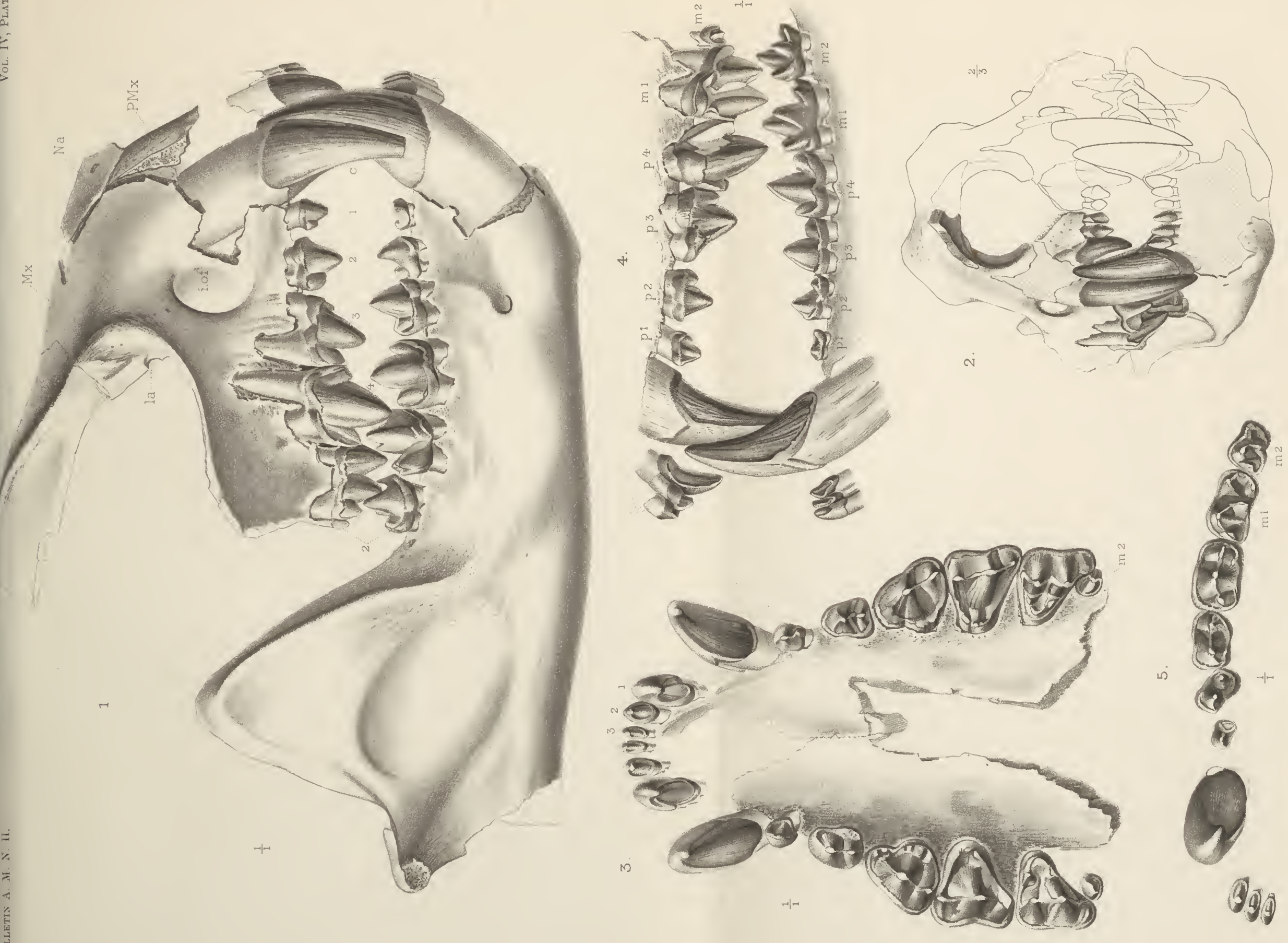

The skull of the type (No. 1 ro) of this species has been described under Section III, page 96 . The dentition is that of a young individual, and is beautifully preserved. Both of the rudimentary second upper molars were procured, but one of them was unfortunately lost. No other remains were found. All the characters of the skull and teeth are brought out in the lithographic plate.

The animal was one-fourth larger than the American Puma (Felis concolor), and slightly larger than either of the specimens referred to Palconictis gigantea by De Blainville and Gaudry. As in $F$.concolor the lower incisors are of nearly equal size; while the upper increase rapidly outwards, the first being very small and the third being large and caniniform. The canines are large, vertically striated and recurved; they exhibit an internal ridge extending from the posterior base to the apex.

Lower Series. - The first lower premolar is low and obtuse with a distinct talon. The second has a pointed protocone, a more elevated talon, and a faint external cingulum. The third has a higher protocone, a prominent basal cusp, and distinct external and internal cingula. The fourth premolar is tricuspid, and exhibits a cusp analogous to the paracone (tetartocone, Scott); also the more elevated basal cusp, rising from the talon and analogous to the hypoconid (=deuteroconid, Scott). The cingulum completely encircles the crown, except at the ends, and upon the inner side of the talon is marked by a little tubercle. The first true molar is a fine example of the typical "tuberculo-sectorial " type. The elevated trigonid supports the lofty protoconid and subequal para- and metaconids, while the talon supports three subequal cusps, the hypoconid, the hypoconulid or posterior intermediate cusp, and the entoconid. The second molar is of much smaller size ; the trigon bears a reduced metaconid, while the talon is still more reduced by the loss of the two internal cusps, the hypoconid alone persisting.

Upper Series. - The first upper premolar is small and single fanged, with a minute basal cusp. The second has quite a prominent basal cusp with a faint external and an internal cingulum shelf. The third premolar has almost a blade or shear formed by the protocone and deuterocone or basal cusp, and a crenate cingulum shelf. The fourth premolar is, we believe, the incipient sectorial; it has the three external cusps which compose the upper sectorial of Felis, but the middle cusp, or protocone, is much the most prominent; this with the posterior cusp (deuterocone) forms a sharp-edged shear, against which abuts the shear formed by the paraconid and metaconid of the first lower molar. Herein lies a close resemblance to the relations of these two teeth in the Felidx, and these molars furnish a simple key to the feline sectorials, as shown in the accompanying diagrams. (Fig. 7.) 
The transformation of the feline upper premolar has taken place by the subequal development, $A, B$, of the three external cusps, $t e, p r$, and $d e$, and by the shifting forward of the internal
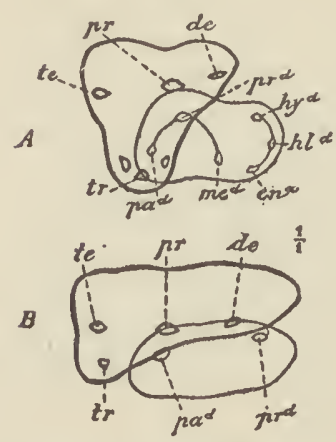

Fig. 7. The homologies of the Molar Cusps in the Felida. $A$, Palaonictis occidentalis. $B$, Felis concolor. de, deuterocone. tr, trittocone. te, tetartocone. Last upper premolar and first lower molar in opposition. cusp tr. Meanwhile the lower molar has lost the entire talon $\left(h y^{d}, h l^{d}, e n^{d}\right)$ and the metaconid $\left(m e^{d}\right)$ is reduced to a rudimentary stage in which it is barely perceptible. This conforms with the description of this transformation given by Cope, ${ }^{1}$ but adds a more exact statement of the homologies of the cusps. The degeneration of the metaconid is well shown in the series of sectorials exhibited in Fig. 5.

The reduced condition of the upper true molars of Palaonictis is most remarkable in an animal of such an early period as the Wahsatch. The third molar has disappeared entirely, the second has been reduced to an extremely small rounded tooth; the first molar is already smaller than the fourth premolar. The pattern of the first upper molar is somewhat similar to that of Oxyeana, but the protocone is directly internal instead of being pushed forwards; the external cusps, paracone and metacone, are subequal and slightly compressed; on the trigon between these high cusps and the low protocone are small intermediate tubercles, $p l$. and $\mathrm{ml}$. There is a prominent cingulum and a posterior basal cusp.

\section{Ambloctonus sinosus Cope.}

The skull of Palconictis renders a great indirect service in enabling us to clear up the structure of the enigmatical Ambloctonus. This was established upon a much fractured maxilla and mandible, by which Cope was wholly misled as to the notation and homologies of the teeth and the relationships of the genus, although in the 'Tertiary Vertebrata' he placed it near Palco-

1 The mechanical causes of the development of the Hard Parts of the Mammalia. Journal of Morphology, Vol. III, r889, p. 232. 
nictis. Schlosser has rightly discerned the resemblance between these forms.

The accompanying figure presents our interpretation of this fractured type. There are two lower molars and but a single upper molar ; the maxilla turns sharply in behind the first molar,

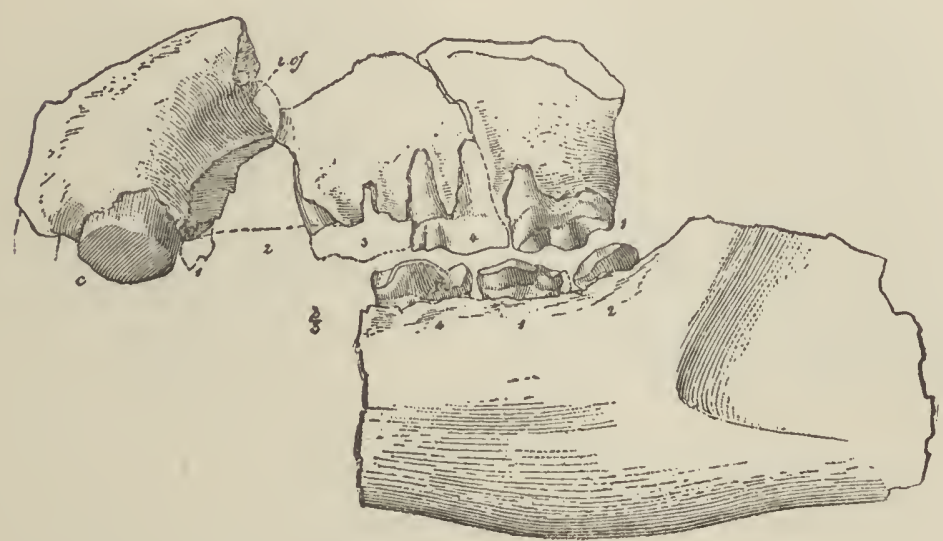

Fig. 8. Ambloctonus sinosus, type specimen, National Museum. This drawing is a composition of the left mandible and right maxilla of the same individual. Three-fifths natural size.

and leaves no doubt as to the absence of both the second and third upper molars. The gap between the fourth premolar and first molar does not contain an extra tooth, as Cope supposed. The tooth Cope mistook for the first molar is really the fourth premolar; the gap in the jaw closes up when the matrix is removed. The superior formula was therefore undoubtedly $\mathrm{p}=4$, $\mathrm{m}=\mathbf{r}$.

This interpretation is supported by the structure of the lower molars, i.e., by the marked degeneration of the talon of $m 2$ which it is obvious has nothing to abut against in the upper jaw. Two stages in the reduction of this talon are shown in Fig. 5; in the type specimen $D$, there is no talon; in a second specimen, rightly associated with the genus by Cope (see Fig. $5, E$ ), there is a rudimentary talon, $t$. 


\section{Family OXY ENID E Cope.}

This family is represented in the collection by eight specimens belonging to the two well-known Wahsatch species, O.lupina and O. forcipata.

\section{Genus Oxyæna Cope.}

They enable us to add several important family and generic characters. Cope has defined the genus as probably possessing no inferior incisors. (I) We find that there are three incisors in both the upper and lower jaws, as in Palconictis. (2) A tarsus of $P$. forcipata in the collection does not support Cope's view that there was a cleft between the third and fourth digits. (3) There is an os-centrale in the carpus. (4) The lumbar vertebræ have involuted zygapophyses. (5) The femur has a faint rugosity representing the third trochanter.

\section{Oxyæna lupina Cope.}

We have referred to this species portions of three lower jaws (Nos. 102, 103, 104), and a fragmentary lower molar (No. 105); also the fairly complete skeleton and teeth of a single individual (No. 107).

The Manus of Oxyana.-As noted by Cope, the skeleton of Oxyrena is much smaller and lighter in proportion to the skull than in the Carnivora.

The scaphoid rests upon the trapezium, trapezoid (which is the only carpal missing), and centrale. It is entirely distinct from the lunar. The lunar rests inferiorly, by nearly subequal facets, upon the centrale and unciform, with a narrow anterior and broad posterior contact with the magnum. The cuneiform rests upon the oblique outer surface of the unciform. The trapezium is depressed so as to form a lateral internal support for the second digit. The magnum presents a subquadrate anterior outline. The unciform has an internal contact with the middle digit, and an oblique external facet for the fifth. The metapodials are much shorter, more spreading, and less firmly interlocking than in the Felidæ. 
Skeleton of the Limbs and Arches.-The humerus has a very

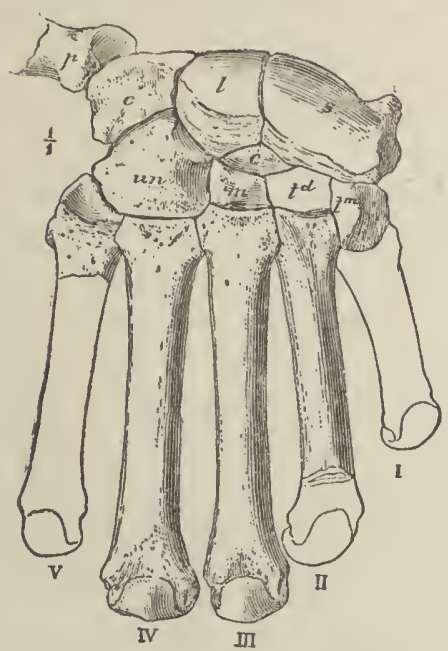

Fig. 9. Oxycena lupina. Right manus, nig. 9. 0 size. prominent deltoid ridge, and an entepicondylar foramen; the trochlea presents, anteriorly, subequal faces for the radius and ulna. The ulna presents, distally, two facets-one for the radius, the other for the cuneiform. The femur presents a pit for the round ligament, a prominent lesser trochanter, and a slight rugosity representing the third.

The lower jaw presents a broad thin angle, and a sharp narrow coronoid process. 'The roller of the condyle tapers sharply, as in Felis.

\section{Oxyæna forcipata Cope.}

We have referred to this species portions of two skeletons (Nos. I08, I09), distinguished by the heavy character of the bones. They include a tarsus, which agrees closely with that referred to this species by Cope, with the exception noted above. The former has two lower teeth associated with it, but they are so broken that the reference is uncertain. A jaw (No. ro6), containing fragmentary molars, may also be placed here.

The tarsus (No. ro9) is extremely interesting, as it appears to prove that Cope is mistaken in his description of the hind foot of Oxyana. The calcaneum is complete and presents an oval ectal facet and a subcircular sustentacular facet. 'The astragalus lacks the outer portion of the tibial trochlea; Cope's figure indicates that the tibial facet is very limited in the fore and aft direction, and that therefore Oxyana was a plantigrade; unfortunately this pes does not throw any light upon this point. A very striking feature of the foot is the broad contact between the cuboid and astragalus ; the cuboid is, as represented by Cope, directed outwards, but the ectocuneiform is in close contact with it, proving that 
there could not have been a cleft between the third and fourth toes. The entocuneiform is a high narrow bone; the mesocuneiform was evidently shorter.

The femur (No. I08) is remarkable for its heavy distal extremity, and its clumsy tibial and patellar facets. The tibia is correspondingly massive. The dorsals and lumbars are partly preserved. The latter have a short, rather obtuse, transverse process, and elevated zygapophyses interlocking by strongly concavo-convex facets.

\section{Family PROVIVERIID A.}

\section{Genus Stypolophus Cope.}

This genus is represented by eight specimens (Nos. 94-101), some of which are in good preservation. There are three specimens (Nos. 96, 97, 98) belonging to $S$. zellitice Cope; two are referred to the smaller form S. viverrinus Cope (Nos. 94, 95); and one well-preserved specimen is much larger than any form of Stypolophus hitherto described (No. 99).

\section{Family MIACID $\notin$.}

\section{Genus Miacis Cope.}

Dentition $\mathrm{I}_{3}, \mathrm{C}_{\mathrm{I}}, \mathrm{P}_{4}, \mathrm{M}_{3}$. First true molar tuberculo-sectorial; second and third molars tubercular.

\section{Miacis canavus Cope.}

A lower jaw (No. 83), which represents this species, has the symphyseal region well preserved, and enables us to determine the alveoli of three incisors, the number of these teeth having been hitherto unknown. The symphysis is narrow, and the alveoli are very crowded, indicating that the incisors were rather small. As described by Cope, the canine is large and compressed; the first premolar is single rooted; the second has two small roots; the third is larger; the fourth consists of a trenchant protocone, with faint anterior and a well-defined posterior basal cusp. The first molar is tuberculo-sectorial, with a rounded talon; the second is tubercular; the third is missing, and is represented only by the small alveolus. 
There is a single second or third upper molar of the right side belonging to another individual (No. 85 ), which we provisionally refer to Miacis. It is distinguished from the corresponding teeth in Stypolophus by the broad external extension of the cingulum which supports no less than four low conical cusps outside of the typical pair of external cusps - the paracone and metacone. The intermediate tubercles are fairly well developed; the protocone is prominent.

Several other specimens can only be provisionally determined. A fragment (No. 84), containing the two lower tuberculars, we refer to $M$. brevirostris, as it is found in the Wind River. A second specimen (No. 87 ) contains a first lower tubercular of an individual much smaller than $M$. canavus, and there is a still smaller specimen (No. 86), which agrees in size with M. cdax Cope, from the Bridger.

\section{Genus Didymictis Cope.}

This genus is characterized by two lower molars, one of which is of a tuberculo-sectorial type, while the other is tubercular and usually is a long somewhat narrow tooth. A well-preserved anterior triangle (trigonid) characterizes the Wahsatch species. The following determinations are not critical; they are based wholly upon Cope's diagnoses.

The two smallest jaws in the collection may be referred to the smallest form, $D$. dazukinsianus Cope (Nos. 89, 90). Together they contain the third and fourth premolars, and first and second molars. They are even smaller than Cope's types.

A much larger individual (No. 92) agrees with the type of $D$. curtidens Cope; this contains the first and second molars. The second molar, which has not been previously described, is long and rather narrow, with the typical three tubercles upon the trigonid and an elevated talonid. A second specimen (No. 93), containing the fourth premolar and first molar, may be referred to the same species, although the individual is somewhat smaller.

$D$. leptomylus Cope is represented by the posterior portion of a right mandible, an upper molar and numerous fragments. The upper molar resembles those of Stypolophus whitice; it has a single prominent tubercle upon the external cingulum. 


\section{Family MESONYCHID E Cope.}

This family, which is so well known through the writings of Cope and Scott, extended from the Puerco into the Bridger period. It is represented in the present collection by two species of Pachyana, one of them new, and by a small jaw which we provisionally refer to Dissacus, a genus hitherto found only in the Puerco.

\section{Dissacus leptognathus, sp. nov.}

The species is distinguished from the Puerco forms ( $D$. navojovius and $D$. carnifex Cope) by the extreme reduction of the postero-internal cusp (metaconid) of the trigon, which is partly separated from the protoconid.

The type is a portion of a small right mandible (No. 78), containing the second true molar complete and the broken crowns

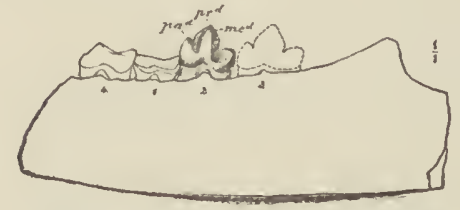

Fig. Io. ? Dissacus (Pachyana) leptognathus, type. Inner aspect of right mandibular ramus. of the first molar and fourth premolar. It is reproduced, natural size, in the accompanying figure, and is about half as large as the types of the Puerco species. The characters of the molar cusps are evidently transitional between those of Dissacus and Pachyana, so that the species might be referred to the latter genus.

The fourth premolar has a single main cone, the protoconid, and a sharp thin basal cusp or talon. The second molar has a small paraconid in the same line with the protoconid; the latter has a faint trace of the metaconid upon its inner slope ; the hypoconid is proportioned as in Pachycena.

\section{Pachyæna ossifraga Cope.}

The Wahsatch Pachycena is distinguished from Mesonyx of the Bridger by the possession of three true molars in both jaws. The formula is $\mathrm{I} \frac{3}{2}, \mathrm{C} \frac{1}{1}, \mathrm{P} \frac{4}{4}, \mathrm{M} \frac{3}{3}$. The last upper premolar is molariform.

The only Wahsatch species hitherto known is the $P$. (Mesonyx) ossifraga Cope. We find three specimens in the collection which 
we can refer to this species. They consist of scattered lower teeth (No. 74); a fairly perfect left mandibular ramus, containing the third and fourth premolars and first molar (No. 75); and a single lower molar (No. 76).

\section{Pachyæna gigantea, sp. nov.}

This species is founded upon a series of finely-preserved upper cheek teeth lacking only the first premolar. The specific distinc-

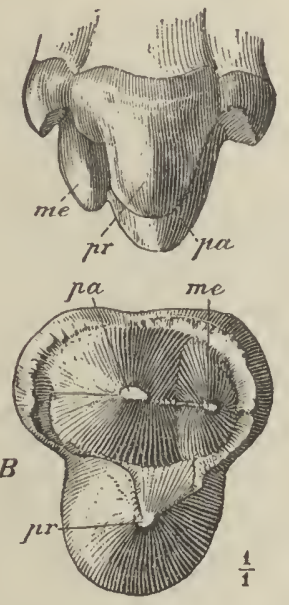

Fig. Ix. A, Pachyana gigantea, first superior molar of type, internal and crown views. $B$, Pachyana ossifraga, type, fourth premolar or true molar, same views (National Museum). Both figures natural size. tions from $P$. ossifraga are very marked :- $(a)$ the presence of a metacone upon the third upper molar; (b) the more complex structure of the third and fourth premolars; $(c)$ the very broad crenate external cingulum; $(d)$ the relatively smaller size of the metacone in the molars.

The name is given in reference to the very large size of the animal. Prof. Cope estimates that $P$. ossifraga was as large as the largest Grizzly Bear (Ursus horribilis). Prof.

Scott ${ }^{1}$ has shown, however, that the Mesonychidæ were characterized by very large heads, and small, rather feeble bodies. Even with this reservation, while $M$. lanizs, as restored by Scott, was $4 \mathrm{I} / 2$ feet long, $P$. ossifraga must have been over five feet, and $P$. gigantea was over seven feet or more than two metres in length. This is by far the largest of the Creodonta excepting the Mesonyx uintensis of the upper Eocene.

The main features of the teeth are $(r)$ the very prominent cingulum; (2) the small size of the second external cusp (metacone);

${ }^{1}$ Journ. Acad. Nat. Sci. Phila., Vol. IX, 2d Ser., Pl. VI, 1886.

[October, 1892.] 
(3) the prominent ridge upon the postero-external slope of the protocone.

The second premolar is fractured upon the inner side, leaving us in doubt as to whether there was an internal cusp. The protocone is a high and compressed cone with a slightly ovate pos-

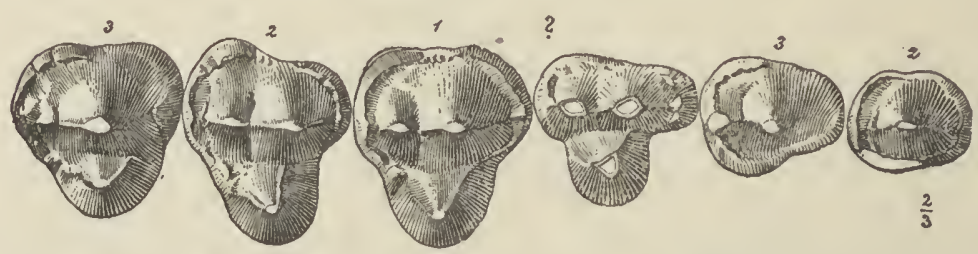

Fig. 12. Pachyana gigantea. Crown view of superior molars of right side. Two-thirds natural size.

terior edge. In the third premolar the postero-internal cingulum rises into the basal talon (deuterocone); also into the internal basal shelf (trittocone), proving that both these cusps arise as cingules in the premolar series. The corresponding tooth in $P$. ossifraga has no internal lobe, as figured by Cope. The next tooth is completely molariform; it is much larger than the preceding, and much more worn than the first molar, suggesting the possibility that it may be a milk tooth, or that in this species the fourth premolar may receive an unusual amount of wear. Since all the teeth are isolated the position of the premolars is somewhat uncertain.

The first true molar presents a complete external cingulum rising at either end of the external lobe into high cingules; the metacone is much smaller than either the protocone or paracone. The second and third true molars exhibit a slight reduction in size; the external cingulum is less complete, and the metacone is gradually reduced.

Another specimen (No. 73), belonging to the same species, confirms the characters here assigned as distinguishing $P$. gigantea from $P$. ossifraga. In the true molars which are all well preserved, the metacone is even more reduced than in the type.

In premolar development $P$. gigantea is more progressive, but in the typical structure of the third molar it is more primitive than P. ossifraga. 
The homologies of the lower molar cusps of these genera are rendered fairly certain by their derivation from those of Dissacus; the anterior cusp is the paraconid, the middle cusp is the protoconid, the posterior cusp is the hypoconid, the metaconid has entirely disappeared. The homologies of the upper cusps are somewhat uncertain; they appear to represent the typical trigonodont pattern with the protocone as the internal apex, and the paracone and metacone as the external base.

\section{Family ARCTOCYONID $\approx$ Cope.}

In this family we include the Creodonts with low crowned tubercular molars, as distinguished from those with one or more sectorial teeth. It contains Arctocyon, hitherto found only in France. We may, with Schlosser, provisionally add some of the forms described by Cope under Mioclanus of the American Puerco, and increase the list by Anacodon of the Wahsatch.

Anacodon was founded by Cope ${ }^{1}$ in $188 \mathrm{I}$ upon a portion of a lower jaw and some fragmentary lower molars. It has since remained one of the enigmas of the Wahsatch fauna. He placed it provisionally in the Phenacodontidx. ${ }^{2}$ The more complete material at our disposal still leaves its position somewhat uncertain, since we have no remains of the skeleton, but renders it very probable that it is a Creodont of a highly specialized type.

\section{Anacodon ursidens Cope.}

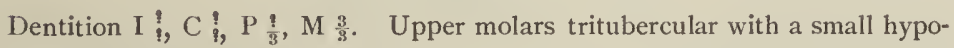
cone. Lower molars quadritubercular. Premolars small, reduced in size and number. Coronal pattern obscured by crenulation of enamel.

There are three specimens in the collection, all of which were found in the uppermost Wahsatch strata. The first (No. 80) is a fragment of a lower jaw with the first and second molars in situ. 'The second (No. 8I) consists of portions of two jaws with three molars, two premolars, and three upper molars. The third (No. 82 ) includes a palate with the upper molars and one premolar

\footnotetext{
1 Proc. Am. Phil. Soc., r881, p. 181.
}

2 Tertiary Vertebrata, p. 427. 
I 6 Bulletin American Museum of Natural History. [Vol. IV,

(Fig. I3) and the first and second lower molars. The latter corresponds in size with the type of $A$. ursidens Cope. The former two are smaller, but cannot be distinguished specifically. Both upper and lower series present a large second true molar, in front of which the teeth diminish rapidly in size, the fourth premolar is decidedly smaller and simpler than the first molar. The third premolar in the lower jaw is a diminutive tooth ; this is preceded by a diastema indicating that the first and second premolars were still more reduced or possibly wanting. The first characteristic of the genus therefore is the striking reduction of the premolars which sharply distinguishes it from any of the Ungulates, as well as from any known Creodonts.
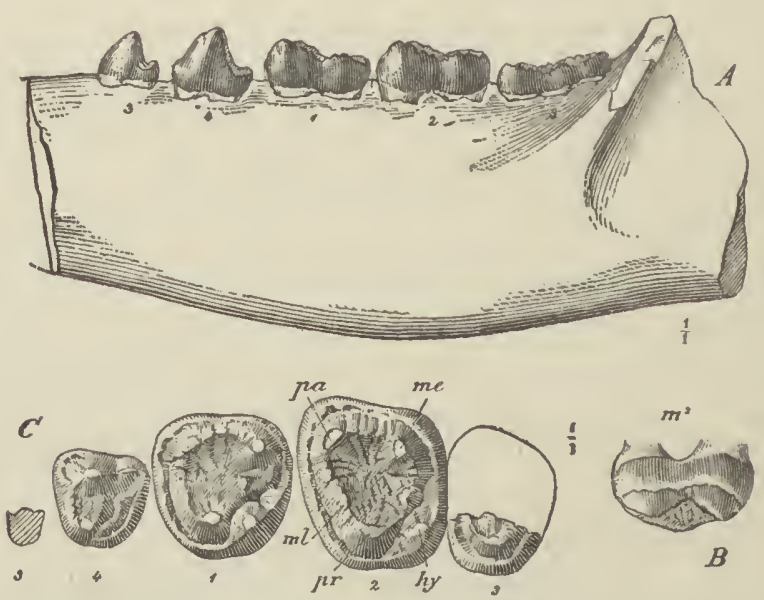

Fig. 13. Anacodon ursidens. A, Internal view of lower jaw. B, Crown view of upper molars. C, External view of second upper molar. Natural size.

The second characteristic is the excessive number of minute tubercles which cover the crown, and the extremely depressed summits of the cusps.

The upper true molars (Fig. I3, $B, C$ ), are completely sur-s rounded by a cingulum, and upon the roughened unworn surface of the second we can just distinguish faint traces of the intermediate conules, $p l$ and $m l$. Even the protocone is depressed; the talon is well developed in $m 2$, giving the crown a subquadrate outline, but $m_{I}$ and $m_{3}$ are more triangular. There is in fact no 
evidence of a hypocone upon $m_{3}$, and it is feebly developed upon $m r$. The external cusps, $p a$ and me, constitute the most elevated portions of the trigon. Only one upper premolar is preserved ; this shows an elevated external cusp, and prominent internal cusp ; in front of this is the alveolus of a small bifanged third premolar.

The lower molars (Fig. 13,A), consist of four cusps only-the protoconid, metaconid, hypoconid and entoconid. There is no trace of the paraconid or fifth cusp ; and the hypoconulid, which is so prominent in Phenacodus and the Wahsatch Ungulates generally, is very faintly indicated in $m r$ and $m 2$ by a slight elevation between the posterior pair of cusps. The third lower molar, however, has a well-developed third lobe, which invariably arises in the mammalia by a backward extension of the hypoconulid. Unlike the upper molars there is no trace of a cingulum. The fourth lower premolar is just emerging from the jaw (No. 8I). It is only two-thirds the length and width of the first molar, thus presenting an extremely unique disproportion; it consists of a symmetrical protocone, with a concave posterior face and very slight indication of a talon. The third premolar is a diminutive tooth of the same form. In front of this is a diastema.

The characters and dimensions of the jaw are shown in the accompanying figure. The jaw was stout with a deep masseteric fossa. As regards the general structure of the dentition we must emphasize the following peculiarities:

1. The enlargement of the second molar in both jaws, the smaller size of the first and third, and the very marked reduction of the entire premolar series. There is no evidence that there were more than two premolars, and these were very small.

2. The degenerate condition of the cusps of the molars, and the formation of innumerable secondary tubercles or crenations.

3. The probable presence of a wide diastema.

Altogether Anacodon was a degenerate and highly specialized animal.

As regards its affinities they are certainly nearer Arctocyon than any other known fossil form, in fact there are many striking re- 
semblances between these Wahsatch and Suessonian (Cernaysian) genera. ${ }^{1}$ The older species of Arctocyon, the $A$. primarus of de la Fère, have four complete premolars and are much larger, but the type of the more recent species A. gervaisii (type of Hyodectes Cope) has but three premolars, and is of exactly the same size as our smaller specimens of Anacodon; in this species the anterior premolars $p m 2$ and $p m 3$ are being rapidly reduced (Lemoine, op. cit., Plate II), although the fourth is still of large size. Further similarities are seen in the absence of the paraconid in the lower molars, in the broad cingulum of the upper molars, but mainly in the proportions of the upper molars (Osborn, op. cit., fig. 4), and relative development of the hypocone. Lemoine has figured accessory tubercles upon the lower molars of $A$. gerraisii.

The main difference between Anacodon and Arctocyon is the greater reduction in the premolars of the former. In the successive species of Arctocyon we however observe marked incipient tendencies to premolar reduction, which may have been carried further in Anacodon.

If these views are supported by additional evidence, we shall regard the bunodont Creodonta as first seen in Mioclanus of the Puerco, again represented in Arctocyon belonging to a period overlapping the Puerco and Wahsatch, and culminating in the summit of the Wahsatch in Anacodon.

\section{Order AMBLYPODA Cope. Suborder PAN'TODONTA Cope. Family CORYPHODONTIDE Cope.} Genus Coryphodon Oreen.

The collection is very rich in remains of Coryphodon, the typical genus of the Wahsatch beds, including one specimen represented by the fore and hind limbs, feet and pelvis; the cervical vertebræ

\footnotetext{
1 See Lemoine, Etude du Genre Arctocyon. Ann. d. Sciences Naturelles, July, 1878, Vol. VIII, No. x. Also Osborn, A Review of the Cernaysian Mammalia. Proc. Acad. Nat. Sci., Phila., s89o, p. 5 r.

2 This is equivalent to the Coryphodontia of Marsh.
} 
and upper molars of another individual; a complete series of upper teeth of the largest type ; upper and lower jaws of another specimen; the lower jaws of a young individual containing the milk dentition; and a large number of isolated teeth, limb-bones, foot-bones and vertebræ.

All the specific determinations proposed by Cope have, with the exception of the types of $C$.pachypus and of $C$. anax, been based upon the teeth, and the present collection has materially aided in clearing up the great confusion in nomenclature. Mr. Charles Earle, Assistant in Palæontology, has undertaken a complete revision of the nomenclature of the American Coryphodontidæ which will soon be published in this Bulletin. We are indebted to him for all the determinations and references here made.

Coryphodon radians Cope.-This species is represented by a complete series of maxillary teeth, and the cervical vertebræ of one individual (No. 274). There is also a complete series of inferior molars, premolars and canines (No. 259). Also a number of superior molars (No. 267). The above are from the Wahsatch.

From the Wind River beds we also find two last lower molars which cannot be distinguished from those of $C$. radians, together with many portions of the skeleton.

Coryphodon elephantopus Cope-This species is represented by remains of one individual (No. 275), including the occipital and palatine region of a skull containing the true molars and premolars, excepting $p m I$. 'This is very similar to the type of $C$. hamatus Marsh. Another individual (No. 260) contains portions of the third upper molar, of the lower canines and incisors. This species is very similar to the foregoing.

Coryphodon obliquus Cope.-This is represented by a nearly complete lower jaw (No. 276) lacking the incisors, and the upper molars and premolars. The value of this specimen lies in the somewhat unusual association of upper and lower teeth.

Coryphodon anax Cope.-As indicated by the name this is the largest species, and it probably includes $C$. pachypus Cope. The principal specimen is a skeleton without teeth including the 
humerus, radius and complete manus, the left innominate bone, the femur, tibia and fibula and complete pes; of the axial skeleton is included the atlas, axis and several scattered vertebral centra ; also a series of peculiarly coalesced post-sacral or caudal vertebræ.

It is possible that the condition of the caudals found in this specimen was pathological, but they bear a perfectly normal ap.pearance, and point to a unique caudal appendage. Behind the sacrum (which is wanting) we find remains of sub-cylindrical caudal centra, followed by a series of flattened centra which rapidly diminish in size posteriorly; these flattened centra become united together by the adjoining faces, and send out wide flattened transverse processes; but the most peculiar feature is the coalescence of the neural spines and laminæ into a long solid ridge which tapers off posteriorly and anteriorly, and renders this portion of the tail absolutely rigid. The only interpretation of this structure seems to be that the proximal portion of the tail was flexible, while the distal half formed a broad solid plate. The humerous suggestion has been made that this appendage supplied Coryphodon with a steering apparatus while swimming in the Big Horn Lake; it is impossible to make any serious conjecture as to the purpose which such a tail subserved.

\section{I'he Foot Structure of Coryphodon.}

The fore and hind feet of Coryphodon have been figured and described by both Marsh and Cope, yet neither of these authors has given an accurate idea of their real structure. Marsh ${ }^{1}$ has figured both the manus and pes in the digitigrade position like the feet of the Elephant. In Cope's latest paper upon the Amblypoda ${ }^{2}$ he says of Coryphodon and other members of the order, "The feet are always short and plantigrade." Elsewhere, ${ }^{3}$ however, he speaks of the movements of the Coryphodons as resembling those of the Elephant (i. e., digitigrade); Cope's figures correspond with those here published, but fail to represent the actual position of the feet.

\footnotetext{
1 Dinocerata, p. 184, figs. 150, 151 .

2 American Naturalist, Nov., 1884 , p. $x x$ Io.

3 Tertiary Vertcbrata, p. 524.
} 
The fact is that the positions of the fore and hind feet of Coryphodon were absolutely different, the fore foot was digitigrade

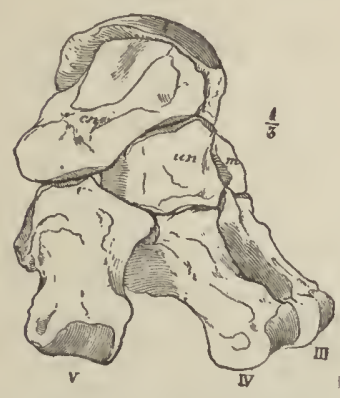

Fig. I4. Coryphodon. Right fore foot, external view, exhibiting Cuneiform, $c n$, resting upon fifth metacarpal, $V$. (National Museum). One-third natural size.

accompanying figures.

We may therefore restate the characters of the feet of the Coryphodon as follows :

\section{Manus.}

Digitigrade. Digits, five.

Scaphoid small.

Lunar enlarged, displaced upon unciform.

Trapezoid small.

Second metacarpal with a large magnum facet.

Third metacarpal with a large unciform facet.

\section{Variations.}

Cuneiform articulates with fifth metacarpal (see' Fig. I4.)

Fibula not articulating with calcaneum. Tibiale facet upon astragalus reduced. An 'astragalar foramen' (for flexor communis tendon).

The absence of the fibular facet upon the calcaneum has been observed in a specimen in the Smithsonian collection; also the cuneiform resting upon the fifth metacarpal. These differences, 
as well as the variations in the tibiale facet, require fuller investigation.

It will be noted that the manus has many points of functional parallelism with that of the Elephant, especially the enlargement of the lunar. The pes, on the other hand, is much more primitive than that of the Elephant.

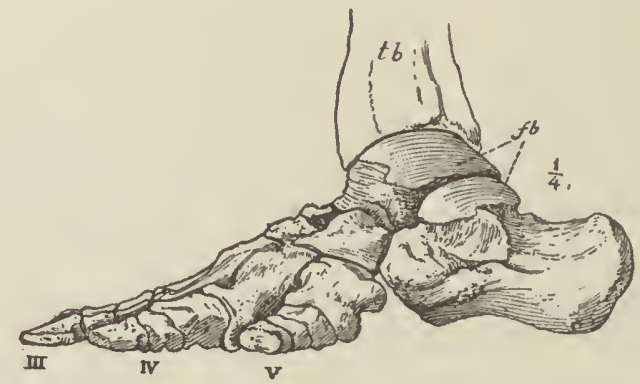

Fig. 15. Coryphodon anax. Left hind foot, external view of the foot in the natural position. One-fourth natural size.

The figure of the pes of Coryphodon given by Marsh is somewhat similar to that of Uintutherium (Dinoceras), and is wholly different from those belonging to Coryphodon in the collections we have examined, since the astragalus is represented as corering the entire upper surface of the cuboid, and, as above noted, the foot is represented as digitigrade instead of plantigrade; the figure of the manus agrees with those we have examined, except that it is of a higher, narrower type. This author rarely errs in his figures, but in this case it would appear either that the astragalus is wrongly figured, or that these feet belong to some of the Dinocerata.

\section{The Homologies of the Molar Cusps in Coryphodun.}

While leaving to Mr. Earle the full discussion of the evolution of the molars of the Coryphodons, as indicated by the numerous variations in the molar pattern, the homologies of the molar elements with those of Pantolambda and of the Perissodactyla may be briefly pointed out. Cope is correct in the interpretation of the lower molar elements, but his interpretation of the upper molar homologies is much more uncertain. We have three means of determining the latter. 
I. The comparison with the molars of Pantolambda.

2. The actual typical structure of the molars.

3. The vestiges of ancestral structure seen in specific variations.

The molar teeth of Pantolambda are tritubercular. There are two external subequal selenoid cusps, the paracone and metacone, separated by a slender median buttress, or mesostyle, with a strong anterior buttress, or parastyle ; there are two faintly-marked intermediate tubercles, protoconule and metaconule, and a strong selenoid protocone; there are also anterior and posterior cingula.

The question is how has this selenodont molar been transformed in to the lopho-selenodont molar of Coryphodon? Cope considers that the anterior crest, or protoloph, of the Coryphodon molar represents the union of the protocone and parastyle; that the median external cusp is the greatly reduced paracone, while the postero-external crescent certainly is the paracone. This theory is rendered clear by. a study of the Anchitherium molar, and it is supported by this comparison, because it is shown in the Equidæ that where there are two external crescents the protoloph is formed by the union of the protocone with the protoconule and parastyle.

Another interpretation is the following: that the protoloph of Coryphodon represents the union of the protocone with the paracone ; that the median external buttress represents the mesostyle ; this is supported by the fact that the antero-external cusp in Coryphodon is often sub-crescentic as in C. radians.

Upon the whole, however, the evidence seems to favor Cope's theory. It is interesting to observe that in examining a large number of Coryphodon molars we find traces of the protoconule and metaconule; also faint traces of the mesostyle.

The anterior crest in the Coryphodons is therefore probably homologous with the anterior crest in the Perissodactyla, especially in the form exhibited in the Equidæ; the posterior crest (or metaloph) of the Perissodactyla is wholly wanting in Coryphodon; the external crest (ectoloph) of the Coryphodontia is homologous with the ectoloph or the posterior crest in the Dinocerata. 


\title{
Order PERISSODACTYLA.
}

Family TAPIRID $\approx$.

\author{
Subfamily SYSTEMODONTINA. \\ Genus Systemodon Cope.
}

Dentition: $\frac{3}{3}, \frac{1}{1}, \frac{4}{1}, \frac{8}{3}$. Superior dental series continuous. First lower premolar contiguous to canine, followed by narrow diastema. Third and fourth superior premolars with two external cusps and a single internal lobe. Paracone and metacone subequal, conic. Protoloph and metaloph complete. I.arge third lobe upon third lower molar.

This Eocene Tapir ranks next to Hyracotherium in abundance during the Wiasatch period. In this collection there are nearly

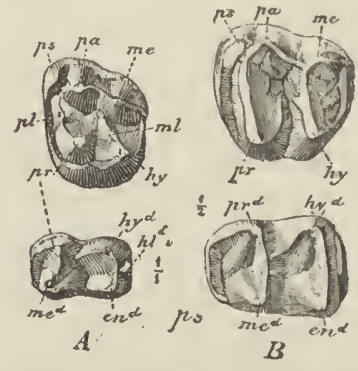

Fig. 16. Systemodon and Tapirus, first Superior and Inferior Molars. $A$. Systemodon semihians, showing Primary Cusps and Parastyle. $b$, Tapirus indicus, showing complete crests. fifty specimens which may be referred to it, including numerous lower jaws and sereral fragmentary skulls. The only skeleton preserved embraces portions of a hind foot which unfortunately is of somewhat doubtful reference, as the associated teeth are only partially preserved. As Cope has shown, there are strong grounds for considering Systemodon an ancestor of the Tapirs, and certainly the Tapir stamp in the molar teeth is most striking, as shown in the accompanying figures (Figs. 16, I 7) yet our opinion must be reserved until we learn the foot structure with certainty.

There are two species, S. tapirimus Cope, and S. semilizans Cope. Our material enables us to distinguish them somewhat more clearly than Cope has done as follows :

S. tapirinus.

Superior.-Internal lobe of second premolar large (Cope).

Intermediate tubercles merged into crests.

External cingulum reduced.

Inferior. - Posterior intermediate cusp (hypoconulid) rudimentary.

Metaconid single.

\section{S. semihiuns.}

Same lobe small (Cope).

Same more distinct; crests interrupted.

External cingulum complete.

Same cusp, distinct.

Metaconid reduplicate (with metastylid). 
The above tables make it evident that $S$. semihians is the more primitive form. In fact it is the most perfect example we know of, of the transition from the primitive bunodont into the pure lophodont type.

\section{Systemodon tapirinus Cope.}

This species includes the larger forms, and is much the most abundant.

A crushed skull (No. I 49) shows that there was a delicate but prominent sagittal crest. The orbits were not enclosed, but protected posteriorly by a postorbital knob. The premaxillæ extended well upwards upon the side of the face. The nasals were slender, pointed and continued well forward, so that the nostrils were terminal. The lower jaw (No. 234) had a wide angle, and a small slender coronoịd process strongly recurved; the condyle is very elevated; it faces upwards and is very slightly convex.

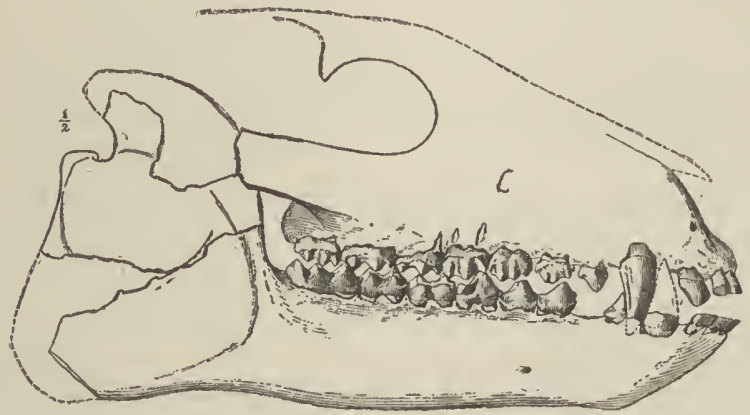

Fig. 17. Systemodon tapirinus. View of skull and lower jaw. Composition from two individuals.

The Dentition.-The most novel features of the collection are two specimens (Nos. I44, I50), containing the premaxilla. The upper and lower incisors have obtusely pointed recurved crowns. The upper canines are large, vertically placed, and with sharply pointed tips; there are two types of lower canines, probably owing to sexual variation, one erect and prominent, the second slightly procumbent and shaped like the first premolar. Cope has noticed the absence of diastemata in the upper series; in the lower series we observe, as a very marked characteristic of the 
genus, that the first lower premolar adheres closely to the canine, and is followed by a diastema.

The importance of the position of the first lower premolar has not been sufficiently emphasized as differentiating the different lines of Perissodactyla we observe $(a)$ that in the primitive Tapirine forms the first premolar is placed immediately behind the canine ; $(b)$ in the Equine forms, it is in the middle of the diastema between the canine and the second premolar ; $(c)$ in the rhinocerotine forms it is always placed behind the diastema close to the second premolar. By this simple law the early representatives of these three lines may be readily distinguished.

The Skeleton.-Many portions of a fragmentary skeleton are associated with a lower jaw and teeth (No. 234), including an astragalus, calcaneum, cuboid, two cuneiforms, several metapodials and proximal phalanges. The tarsus is of a more contracted type than we had anticipated would be found. The astragalus and calcaneum are strikingly like those of Heptodon; the cuboid is, however, much shorter, and the tarsus was therefore proportionally shorter and broader. As in Heptodon and Hyracotherium there is no lateral displacement, the astragalus having a very narrow contact with the cuboid. There were evidently but three digits with well-marked posterior keels. The phalanges are long and slender; unfortunately the distal ones are not preserved.

The head of the femur is perfectly round with a decided pit for the round ligament.

\section{Systemodon semihians Cope.}

This species includes the more primitive and somewhat smaller forms from the Wahsatch.

The specific characters of the teeth are both progressive and retrogressive. 'The retention of the posterior intermediate tubercle upon the lower molars is an inheritance from the Condylarthra in which this cusp is invariably present; the broad external cingulum, the low crests, and the still apparent intermediate tubercles of the upper molars are also primitive marks. The appearance of an accessory tubercle (metastylid) behind the metaconid is, on the other hand, a secondary character; it seems to be more distinctly developed in this species than in S.tapirinus. 


\section{2.-The Wind River Fauna.}

The Wind River collection includes portions of the fore and hind limbs and the complete jaws of Palcosyops borealis, also the jaws and nearly complete fore and hind limbs of Heptodon calciculus.

\section{Family HELALETID $Æ$.}

Small perissodactyl mammals extending from the lower Eocene to the lower Miocene. Molars lophodont ; paracone and metacone of same size; metacone flattened and placed internally. Ectoloph incomplete, or notched, as in Tapir. Protoloph and metaloph complete. Feet tending to monodactylism, lateral digits shorter than median digit. Terminal phalanges compressed.

This family includes Heptodon of the Wahsatch and Wind River, Helaletes of the Bridger, and a White River (Miocene) genus which cannot be defined because the premolars are unknown.

\section{Genus Heptodon Cope.}

Dentition : $\mathrm{I}_{\overline{3}}, \mathrm{C} \frac{1}{1}, \mathrm{P} \frac{4}{4}, \mathrm{M} \frac{3}{3}$. Last inferior molar with a small heel. Third and fourth superior premolars with single transverse crests, well-developed external crests and anterior buttress. Digits 4-3.

\section{Heptodon calciculus Cope.}

Dentition.-Nine of the twelve upper and lower incisors are preserved and exhibit spatulate to chisel-shaped crowns. The canines are rather slender and finely pointed. The first upper premolar is bifanged and, as in all the rhinocerotiform group, is behind the diastema and close to the second premolar. 'The latter tooth has a single protocone and a broad internal shelf. The third and fourth premolars exhibit an anterior buttress (parastyle), and two conic external cusps ; there is a well-defined anterior crest (protoloph), and an incipient posterior crest (metaloph). The true molars have the conic paracone and flattened metacone which Cope has pointed out as characteristic of this line, the latter has a postero-external cingulum; the crests are sharply defined. 
In the lower jaws we find a corresponding diastema behind the canine and a small single-fanged first premolar. This differs from Cope's type (Tert. Vert., p. ${ }_{56} 6$ ) in which the first premolar is wanting on one side. The second premolar has a narrow posterior talon. The third premolar is less advanced than the corresponding upper tooth, since the anterior and posterior crests are in the most incipient stage. The fourth premolar shows a well-marked metalophid, or anterior crest, and a crested talon. Each of the true molars exhibits a spur extending inwards from the protoconid which represents the primitive line of connection with the paraconid and with a similar fold from the hypoconid to the spurs from the anterior and posterior crests of the rhinocerotiform inferior molar. The third lower molar has a conic third lobe (hypoconulid), which it is very interesting to trace among Bridger successors of the genus.

Lower Jazos.-The lower jaws are beautifully preserved and are remarkable for the slender coronoid process, the elevated condyle, the widely rounded posterior border of the angle. The symphysis extends as far back as a line drawn vertically below

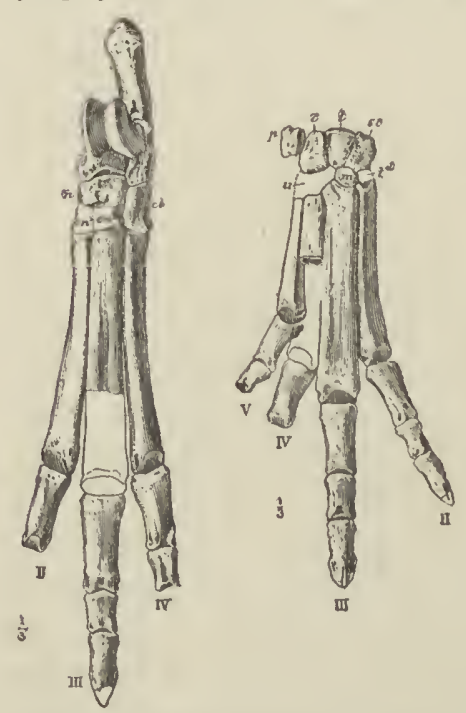

Fig. 18. Heptodon calciculus. Left hind foot. Right fore foot. One-third natural size. the second premolar. The skull is wanting.

Fore Limb.- The limbs as well as the dentition indicate that this individual was not fully mature. The humerus has elevated greater and lesser tuberosities, and a deep, single, bicipital groove; distally, there is a sigmoid radial trochlea, above which is an oval supratrochlear foramen; the internal condyle is slightly more prominent than the external. The ulna and radius are well preserved; they are elongate, slender and arched forwards. 
The Manus.-Several of the carpals are preserved; the proportions of the wrist are similar to those in Hyrachyus, that is, high and rather narrow. The displacement is similarly advanced ; the scaphoid rests widely upon the magnum; the lunar retains a narrow magnum facet and rests mainly upon the unciform; the magnum has an elevated posterior process articulating between the lunar and unciform. The metapodials are of unequal lengths and as a whole shorter than in the Bridger forms, the central metacarpal being $25 / 8$ inches in length, while the second and fourth are $3 / 8$ of an inch shorter; there are sharp keels upon the posterior distal surfaces. The proximal phalanges are much the longest; the distal phalanges are long and much compressed with a deep distal median groove."

The pes is much longer and stouter than the manus, with a high narrow tarsus, three stout digits and elongate phalanges. The calcaneum is high and compressed, with a superior fibular facet; the ectal facet is separate, but the ental and sustentacular facets are continuous, as in some species of Hyrachyus, with an intermediate groove for a corresponding ridge upon the astragalus. 'The astragalus has a deep tibial trochlea, a narrow navicular facet, but, as in Hyrachyus, it only rests upon the cuboid posteriorly by a narrow facet as in the Equidæ, and not anteriorly as in the Tapirs and Rhinoceroses. The cuboid is elevated and compressed in the centre as in Hyrachyus. The navicular is deep, and has a small external contact with the calcaneum, as in the early Hyracotheriinæ. The external or fourth metatarsal is turned outwards, and has a rather slender oval shaft; the third metatarsal has a stout flattened shaft. The proximal phalanges are long and laterally compressed.

The femur has a small projecting head, an elevated incurved great trochanter, and prominent lesser and third trochanters, with a deep trochanteric fossa; the shaft is recurved, and has a deep antero-posterior section.

The tibia has a double spine, a very long and prominent cnemial crest, and a slight sigmoid or double curvature of the shaft.

Restoration.-The limbs and jaws of this young individual indicate that Heptodon calciculus was a slender digitigrade perisso[October, 1892.] 
dactyl, about forty inches long and eighteen inches high ( $100 \mathrm{x}$ 45 centimeters), with not far from the same dimensions, but of a much more slender type than the Collared Peccary (Dicotyles tajacu). The hind limb was much longer and more powerful in all its dimensions than the fore limb, and points to habits of rapid locomotion. In fact, although the tibia and femur are of equal length, the proportions of the limbs and the extreme lateral compression of the hoofs suggest a resemblance to the Cervida in locomotion rather than to any of the known Perissodactyla.

The feet are extremely interesting because of the elongation of the median digit, and the shortening of the lateral digits; this character is well shown in the manus, and was probably exhibited in the same degree in the pes, but unfortunately the median digit is incomplete distally in our specimen. In other words, $H$. calciculus exhibits a more marked degree of lateral reduction than the contemporary Wind River Horse, Hyracotherium venticolum, which was in a true monodactyl line ; there is, however, no compensating enlargement of the magnum.

This specimen of $H$. calciculus was about half as large again as the Wind River Hyracotherium restored by Cope, and, compared with later Bridger forms, was one-third smaller than the Triplopus cubitalis of the upper Bridger. It is slightly larger than the Palaplotherium mimus of the Débruge of France.

The Relationships of Heptodon and Helaletes.-Cope has placed Heptodon in the ancestral line of Hyrachyus. Osborn has considered it much nearer Helaletes Marsh of the Bridger. Helalctes was placed by Marsh in the ancestral line of the Tapirs, on account of the presence of a small heel upon the third lower molar, but Osborn ${ }^{1}$ has shown that the teeth of Helaletes remove it entirely from any relationship to the Tapirs, and has pointed out the probable generic identity of Desmatotherium Scott and Dilophodon Scott with Helaletes.

The discovery of the skeleton of Heptodon confirms Osborn's view as to the close relation between Heptodon and Helaletes, and enables us to form some opinion as to the phylogenetic relationships of these forms. First a word as to nomenclature. 
The synonomy of Helaletes is rich, as species variously referred by Leidy, Marsh, Scott and Osborn to Lophiodon, Hyrachyus, Desmatotherium and Dilophodon all belong to this genus. It is distinguished from Hyrachyus, and marks an advance upon Hcptodon, by the presence of two internal lobes upon the third and fourth upper premolars. It is further distinguished from Hyrachyus and related to Heptodon by the variable development of the third lobe upon the last lower molar. Marsh attached considerable importance to this character, in making it a basis of tapirine affinity, but in the six or seven specimens from the Bridger beds in the collections of the Philadelphia Academy and of Princeton, the third lobe (hypoconulid) presents every degree of degeneration from a small distinct cusp, as seen in H. boops Marsh, and its synonym $H$. (Hyrachyus) nanus Leidy, to a basal cingulum, as in $H$. (Dilophodon) minusculus Scott. In this genus, therefore, this lobe is merely of specific value, and is rapidly disappearing.

We can now define Heptodon, Helaletes and Hyrachyus, as follows :

\section{Heptodon Cope.}

Premolars $\frac{4}{4-\overline{3}}$. Third and fourth upper premolars with a single crest and single internal lobe. Third lobe of the last lower molar constant. Paracone conic, and metacone flattened, symmetrical, of equal length.

\section{Helaletes Marsh.}

Premolars $\frac{4}{3}$. Third and fourth upper premolars with two internal lobes. Third lobe of the last lower molar variable. Paracone conic, and metacone flattened, symmetrical, of equal length.

\section{Hyrachyus Leidy.}

Premolars $\frac{4}{4}$. Third and fourth upper premolars with two transverse crests and single internal lobe. M3 without third lobe. Paracone conic, and metacone flattened, asymmetrical, metacone longer than paracone.

Heptodon calciculus agrees closely with Helaletes boops in the characters of the tarsus, except that in the latter the two lower facets of the astragalus are not continuous, as observed in Marsh's type individual.

It is clear that Heptodon and Helaletes represent a line of succession contemporary with that of Hyrachyus-Triplopus-Hyracodon, but distinct from it in many characters. The difference is shown in a comparison of the external cusps of the upper molars; in all the three latter genera they are rhinocerotiform; that is, the metacone is much longer than the paracone, and forms a continuous ectoloph. In the Helaletida, on the other hand, the external 
lobes are of equal size, although the paracone is convex, and the metacone concave, and the ectoloph is interrupted as in the Tapirs.

The nearest relatives of this line are therefore not the American Hyrachyus series, but the true Lophiodon series of Europe. It is possible that the Helaletidæ will prove to be a branch of the Lophiodontidæ.

\section{Family TITANOTHERIID死.}

\section{Subfamily PALAOSYOPINA.}

\section{Genus Palæosyops Leidy.}

It is extremely interesting to find a well-advanced species of this distinctively Middle and Upper Eocene animal in the same horizon (Wind River) with the last representatives of the Coryphodontidæ and Phenacodontidæ, so characteristic of the lower Eocene. Palaosyops borealis Cope was an animal only one-fifth smaller than the Brazilian Tapir, $T$. americanus. It was much larger than its contemporaries Heptodon and Hyracotherium, and equaled in size Bathyopsis, the representative of the Dinocerata in the same beds. It was therefore second in size only to Cory'phodon among the Wind River fauna. This fauna is well known as a mixed fauna of Wahsatch and Bridger types.

\section{Palæosyops borealis Cope.}

Superior molars quadrate ; external crescents (paracone and metacone) broad and shallow; mesostyle prominent; protoloph faintly marked upon mI and 2 ; intermediate tubercles (proto- and metaconules) reduced. Inferior third molars with a small conical third lobe (hypoconulid). First lower premolar spacing the diastema.

This species is represented by several portions of the skeleton of a single individual (No. 296), which fortunately supplement the knowledge obtained from Professor Cope's fragmentary type specimen. The specific identification is based upon the fact that the dental series coincides exactly with the upper molars and premolars of Cope's type; the two lunar bones are also exactly similar. They include a complete lower jaw, two cervicals, three dorsals, and a caudal vertebra, a femur and a humerus, and the greater part of a fore foot. 
The jaw is in fine preservation, lacking only the incisors, canines and first premolars. The canines were large and semiprocumbent ; the first premolar was single rooted, and placed a short space behind the canines; the second premolar has a sharp laterally compressed crown consisting of an elevated protocone, and distinct but depressed talon; the third premolar is lower and broader, with a more depressed protocone and a $\mathrm{V}$-shaped talon ; the fourth premolar is submolariform, consisting of two Vs, the metalophid (anterior crest) is well developed with its spur, but the hypolophid (posterior crest) is still wanting. In the first true molars the anterior portion of the crown is higher than the posterior, but in the second molar these regions (trigon and talon) are subequal; the third molar has a small conical third lobe (hypoconulid); the molars increase in size from first to third.

The mandibular rami are characterized by broad, highly convex condyles, slender recurved coronoid processes, deep angles and inferior borders rising rapidly to the narrow, elongate and convex symphyseal region.

The sixth and seventh cervical vertebræ exhibit broad, slightly keeled centra, large arched neural canals, and flat, obliquely placed zygapophysial facets; the spines are broken, but were evidently quite high; the seventh cervical is imperforate. The dorsals belong to the anterior portion of the column; the centra are laterally compressed and trihedral in mid-section; the zygapophyses are small and nearly horizontal, the spines are slender and have a trihedral section, the metapophyses are elevated and slender; the parapophyses are not preserved.

The femur lacks the head. In comparison with the Bridger species it is distinguished by the great prominence of the third trochanter; the second trochanter was also prominent; the great trochanter was slightly below the level of the head; the shaft has a flattened posterior face as in all the known species of Palcosyops.

The humerus has a very deep antero-posterior section in the upper portion of the shaft; the tuberosities are partly broken; the bicipital groove is very broad; the deltoid ridge is more prominent than in the Bridger species; the supinator ridge is normal ; there is a well-marked tuberous projection for the latis- 


\section{I34 Bulletin American Museum of Natural History. [Vol. IV,}

simus dorsi; the supratrochlear pit is imperforate; the condyles are subequal.

The Manus.- The structure of the right fore foot is extremely interesting, because of its functional tridactylism; (I) the upper

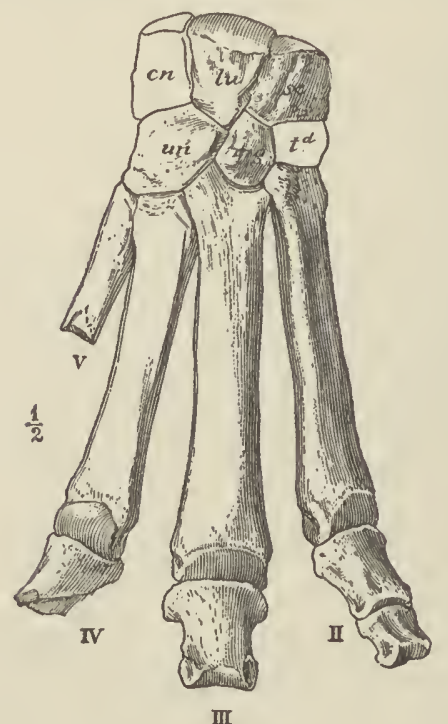

III half of the fifth metapodial is preserved; it is decidedly more slender than the second metapodial. Other proofs of functional tridactylism are: (2) the enlarged third metapodial (Mtc. III), which is much longer than the second and fourth ; (3) the carpal displacement is extreme, the lunar rests wholly upon the unciform, and has a narrow vertical facet for the magnum; (4) the unciform and magnum are high and narrow. In short this foot is distinctively mesaxonic and functionally tridactyl, whereas the later forms from the Bridger are so far as known paraxonic and functionally tetradactyl ; in other words we find an early species with a more progressive and modified type of foot than the later species, a state of affairs which is decidedly inconvenient for the evolutionist.

Affinities.-According to Earle, who has in press an exhaustive memoir upon the Palaosyopina, the affinities of the upper molars of $P$. borcalis are with those of the Bridger species $P$. (Tclmatothcrium) cultridens, which he considers in the persistent line of succession leading to Diplacodon and Titanotherium. The incipient tridactyl foot structure of $P$. borcalis has affinities with that of $P$. (Limnohyops) laticeps of the Bridger, but the latter is of a more pronounced tetradactyl type. Altogether the discovery of the feet leaves the phyletic position of $P$. borealis more uncertain than before. 


\section{V.-Geological and Geographical Sketch of THE Wahsatch Exposures in the Big Horn Mountains.}

The valley or basin of the Big Horn lies in almost the extreme northwestern portion of the State of Wyoming, slightly overlapping the line between this State and Montana on the north. Geographically considered it forms an isolated basin enclosed for the most part by high mountain barriers, which for the greater portion of the year are covered with snow. In consequence of this fact, together with the rugged character of the country, travel is at all times difficult, and it is only during the time that the snow is absent that it can be said to be entirely and easily accessible.

In order that the following brief description of its geology may be made more intelligible, I append a short sketch of the geography of the region.

The present geographical boundaries of the basin are very similar to if not identical with those which enclosed the ancient Big Horn Lake, and it is to be seriously doubted if any considerable local disturbances of level have occurred in this region since the beginning of the Wahsatch epoch. The boundary of the basin upon the west is furnished by the main chain of the Rocky Mountains, which here has a direction almost due north and south.

Upon the east, at a distance varying from fifty to seventy-five miles, lies the Big Horn Range almost parallel with the Rockies. Its northern boundary is indicated by the Pryor Mountains, a spur which puts out from the Big Horn to join the main Rocky range. The general trend of this divide is to the northwest, and it is not so well defined nor so high as either the eastern or western boundaries, especially in its northwestern portion.

Upon the south a well-marked but lower range connects the Rockies with the Big Horn Mountains, and although somewhat irregular in direction, has a general trend east and west. This range is cleft about midway by a deep cañon through which the Big Horn River flows and becomes continuous with the Big Horn Range. 


\section{I36 Bulletin American Museum of Natural History. [Vol. IV,}

To the east of this cañon the mountains are known as the Rattlesnake Range, while on the west they take the name of the Owl Creek Mountains. It is a matter of some interest to note, that while this Rattlesnake-Owl Creek range forms the southern boundary of the Big Horn basin, it also forms the northern boundary of the Wind River basin, which is also the site of an ancient lake which came into existence after the Big Horn Lake was drained.

The basin thus enclosed is about one hundred and fifty miles in length, by from fifty to seventy-five miles in width. It is irregularly oval in form, and has an elevation above sea level of about 3500 feet.

Its drainage is by a number of streams, the principal one of which is the Big Horn River. Above or to the south of the Owl Creek Cañon this stream is known as Big Wind River, but after it passes through the cañon it takes the name of the Big Horn. Its general direction from the Owl Creek cañon to the second gorge, which it has formed in its passage through the Pryor Mountains, is almost due north, and it may be said to lie well to the eastern side of the basin in its passage through it. It finally empties itself into the Yellowstone near Fort Custer, Montana.

Upon the west it receives a number of tributaries, two of which at least are sizable streams at all seasons of the year, and are derived from the melting snows of the high rugged Rockies. The first of these tributaries, beginning upon the north, is Owl Creek, a comparatively small stream, some thirty or forty miles in length, which drains the northern slope of the Owl Creek range, but which goes dry in the latter part of the summer or early fall. Then follow a number of creeks of similar nature whose courses do not extend to the snowy mountains, and which consequently go dry in the summer. They are Cottonwood, Gooseberry, Fifteen-mile, Ten-mile, Five-mile and Elk Creeks, in the order named.

The next tributary is the Gray Bull, a beautiful stream fed by the melting snows from the high mountains to the west. In the spring and early summer it is high, rapid and dangerous, so much so as to interfere materially with our operations in its vicinity during our explorations there. It is said to have a mean fall of 
seventy-five feet to the mile from the point where it enters the basin proper, and its waters are used for irrigating purposes by the ranchers who have settled in its fertile valley.

Stinking Water, also fed by the snows of the Rockies, is the next stream on the north, and is somewhat larger than the Gray Bull. It flows with a rapid descent through a cañon for the greater part of its course, and falls into the Big Horn a short distance to the south of the Pryor Gorge. Its name is derived from the distinctly sulphurous odor of the water caused by a number of sulphur springs along its course.

The two tributaries derived from the Big Horn range upon the east are comparatively small and unimportant streams except in spring when there is rapid melting of the snows, and then they are high and turbulent. No Wood, the larger of the two, reaches the Big Horn some fifteen or twenty miles above the mouth of the Gray Bull, while Shell Creek, the other principal tributary from this direction, empties itself into the Big Horn a short distance above Pryon Cañon or the northern gorge of the main river. As is the case upon the west side, there are in addition a number of small streams which are dry for the greater part of the year. 'The principal one of these is Kirby Creek, which receives the water shed of the northern slopes of the Rattlesnake range, and is the corresponding stream to Owl Creek upon the west.

Another stream which is not a tributary of the Big Horn, but which, properly speaking, belongs to the drainage system of the Big Horn basin, is Clarke's Fork. This stream is about equal in size to Stinking Water, and takes its rise in the high snowy mountains of the main Rocky range to the north of this latter stream. It has formed for itself an independent outlet to the northeast through the low divide which connects the Pryor Mountains with the Rockies, and after gathering a number of tributaries runs parallel with the Big Horn and finally falls into the Yellowstone near the small town of Billings. Its basin, although geographically separate from that of the Big Horn, is geologically a part of it, as I was able to determine after careful examination of its structure.

The general character of the country enclosed within the basin just described may be said, for the most part, to be that of a barren, 
sage brush, bad-land desert, very uneven and badly broken by the irregular weathering of the soft Wahsatch sediment with which it was at one time completely filled. The appearance presented by this sediment at the present time is characteristically that of the bad-land scenery so common in the Rocky Mountain region.

The Big Horn Basin.

Geology.-The geological history of the Big Horn basin is not difficult to decipher, owing to the lack of vegetable growth and the consequent exposure of all the formations entering into its structure. It may be briefly told as follows : Sometime between the close of the Cretaceous epoch and the beginning of the Wahsatch division of the Eocene, the flexure or fold which gave rise to the main Rocky Mountain chain had been elevated, and with it came the subsidiary uplifts which formed the Big Horn range, together with the connecting spurs, the Pryor and Owl Creek mountains. The result of these changes was the formation of an extensive basin walled in by the high mountain barriers already described. There is every reason to believe that the elevation of these mountain ranges was very much more considerable than it is at the present time, since the softer sedimentary rocks have for the most part been removed from their summits, which now exhibit the granitic nucleus of which they are largely composed.

The elevation of these folds took place from the sea-bottom, carrying upwards the older formations which at first formed continuous layers over these mountain ridges, but as the work of erosion and denudation progressed they were removed from the crests of the ranges, and are consequently now represented along the bases of the mountains by sections of their original thickness, tilted up at a considerable angle following the original curve of the fold.

Upon completion of the uplifts the basin became filled with fresh water, and then began the accumulation of that vast layer of sediment which marks the Wahsatch division of the Eocene period.

Gradually the basin was filled with the débris washed down from the neighboring mountain sides, in all probability largely 
derived from the older sediments which were now above water, until finally, after the lapse of a long period of years, measured by the accumulation of a mass not less than 2500 feet in thickness, the waters of the lake found an outlet through one or more of the low mountain passes, and at once began the work of wearing down a channel through them. As this channel was worn deeper and deeper it finally reached a point where the waters of the lake were drained off, and the rivers instead of longer depositing their load of sediment in the still waters of the lake, carried them on seaward. With the drainage of the waters of the lake began the process of scoring out the present valleys of the basin, and the carving out of the lake sediment into the remarkable bad-land stretches that are to be seen to-day.

Although I had no means of accurate measurement I was able to determine the approximate thickness of the Wahsatch deposits by the height of surrounding peaks, together with evidence gathered by the county surveys of certain parts of the basin. Just below the bridge at the crossing of the stage road on the south side of Stinking Water stands a bad-land peak (McCulloch's Peak) which is variously stated to be $I 500$ and $I 800$ feet high. It is composed entirely of Wahsatch sediment from base to summit, as was determined by the fossils in its vicinity. From this peak to the mouth of Stinking Water is a distance of 25 or 30 miles, and it is said to have a fall of 40 or 50 feet to the mile. It passes through Wahsatch beds all the way, and considering the fact that these beds are horizontal, another rooo feet must be added to give the entire thickness of the deposit. This does not take into account the wearing away or erosion that has taken place from the summit of the peak, which, during the long period it has been exposed, must have been considerable. At all events, in the absence of exact measurements, I think it entirely within the bounds of probability to say that the thickness of the sediments of the Big Horn Lake, as they are now exposed, is not less than 2500 feet. King $^{1}$ gives the aggregate thickness of the Vermillion Creek beds, which contain practically the same fauna as the Big Horn deposits, and are without doubt of the same age, as 5000 feet. In a former

\footnotetext{
1 United States Geological Explorations of the Fortieth Parallel, Vol. I, Systematic Geology, p. 360 .
} 
paper which I published upon the subject, ${ }^{1}$ the thicknesses of the Big Horn sediments are given as 4000 feet. This is probably erroneous and was based upon inaccurate computations of the heights of some of the Bad Land Buttes.

Above the bridge at the crossing of Stinking Water the river has cut down to the underlying rocks, and an instructive section is exposed. Here the Wahsatch or Big Horn sediments are seen to lie unconformably upon the older beds. This is shown in many places throughout the basin, and is positive evidence of the fact that there was a distinct break in the deposit of sediment between the older and the newer series. In the Stinking Water section the older formations dip away to the eastward at an angle of $30^{\circ}$ or $40^{\circ}$, while the Big Horn strata lie almost if not quite horizontal.

The question of the age of the older rocks is not easy of solution, and in the almost total absence of fossil remains any exact determination is well nigh impossible. As observed upon the northern slopes of the Owl Creek Mountains the succession is as follows: thick masses of limestone resting apparently directly upon the granite, and forming a large part of the crest of the range; this is followed by an intensely red sandstone layer of considerable thickness which Hayden frequently spoke of as the "Jura-Trias red beds." After this comes a succession of layers of bluish clay alternating with beds of compact brown and rusty colored sandstones. In places these sandstones are interbedded with thin strata of coal, some of which is of good quality. At Red Lodge, Montana, these coal veins are of sufficient thickness to admit of extensive mining operations, and it is from this locality that a large part of the coal supply of this region is furnished.

In the mines at Red Lodge some fossil shells have been found, and among them is to be distinguished a large species of the genus Inoceramus, which Prof. Whitfield informs me is characteristic of the Dakota division of the Cretaceous. In regard to the continuity of the coal-bearing sandstones and clays at the Red Lodge exposures, with similar exposures in the Big Horn region, I do not think there can be any question; in fact, the same exposures 
are met with on the Big Horn side of the divide but a few miles from Red Lodge on Bear Creek, a tributary of Clarke's Fork, and these beds again appear to be continuous with the coal veins found in so many parts of the basin.

Between these coal-bearing strata and the base of the Wahsatch sediments there intervenes a very thick layer of sandstone, which seems to present the same general lithological characters as the underlying sandstones. An exception to this, however, is found in a section exposed on Stinking Water, where the sandstone immediately underlying the Wahsatch contains faint traces of impure lignite. It may be that these beds are to be referred to the Laramie Cretaceous, but if this is true they are very different from the Laramie exposures to the east of the Big Horn Mountains, with which I an personally familiar. King observes," "Between the uppermost members of the Laramie Cretaceous and the lower beds of the Vermillion Creek Eocene, there is but very slight lithological difference. They are both reddish, friable sandy rocks." 'This certainly does not agree with the description of the beds underlying the Big Horn sediments, and it is somewhat doubtful if the Laramie is here represented. I was unable to find any strata that would represent the Puerco deposits, and it is more than probable that this formation is also absent in this region.

The Wahsatch sediments are made up entirely of beds of clay and sandstone. The clays vary in color from a light buff to a brick red, although in some places they have a distinctively bluish or slate-colored tint. 'l'hey contain much lime in the form of small rusty nodules in which the fossils are usually found, and not unfrequently there is much admixture of sand. In other places the sand and clay beds are sharply defined from each other, indicating in all probability rapid changes of the currents of the lake. They are for the most part in an extremely fine state of division, and were undoubtedly derived principally from the erosion of the older Cretaceous and Jurassic formations. The sandstone layers, upon the other hand, are composed of much coarser materials, and very rarely contain the lime nodules seen 
in the clay. They vary in thickness from one to twenty feet, and in some instances even more. When first exposed they are somewhat bluish in color, but owing to the presence of iron they assume a decided rusty color after much weathering.

The fossils are found almost exclusively in the clays, although their occurrence in the sandstones is not unknown. In the clays they are in a majority of instances badly broken and crushed, caused no doubt by the settling and packing of this sediment. In the sandstone, upon the other hand, the bones are generally well preserved, and nearly all of the choice specimens have been derived from this material.

The principal fossil bearing exposures are found in the vicinity of the Gray Bull and Stinking Water, although Buffalo Basin, which is really the upper part of the basin of Fifteen Mile Creek, also contains some good exposures. The exposures without exception face to the northwest, a fact which is explained by the prevailing direction of the storms in the winter and spring.

The basin of Clarke's Fork, although generally regarded as having been filled with deposits of Cretaceous age, is identical in its structure with the Big Horn basin proper. The older formations are the same, and I was able to trace the continuity of the Wahsatch deposits across the high divide, or mesa, from Stinking Water. Not content with this evidence I made careful search for fossils in the exposures of the Clark's Fork basin, and was rewarded by the finding of enough material to settle the age of these beds without further question. The remains are all mammalian, and the species represented are characteristically those of the Wahsatch.

\section{The IVind River Basin.}

There yet remains to discuss the relationship between the Big Horn and Wind River Lakes. As already indicated, the Wind River basin lies to the south of the Big Horn basin, and is now drained by the same river system, viz.: by the Big Horn and its continuation, the Big Wind River. The Wind River or upper basin was filled with sediment in the same manner as that of the Big Horn, but it is of a later age as is abundantly demonstrated by the fauna it contains. 
Now the Owl Creek-Rattlesnake range, as already remarked, formed the southern boundary of the Big Horn Lake and the northern boundary of the Wind River Lake, and the question naturally arises, how can it be that the upper basin is later in age? One would naturally suppose that the upheaval of the Owl Creek Mountains, which formed the southern boundary of the Big Horn Lake, would have also cut off a basin to the south, and that the lower strata of the Wind River deposits would be of the same age as those of the Big Horn. Such, however, is not the case. Every part of the Wind River sediment, from base to summit, belongs to a later geological epoch.

The Wind River Lake was surrounded by high mountain ranges, and its deposits were of great thickness, equal perhaps to that of the Big Horn. How can this be explained?

In trying to make out this problem there was one fact that struck me as very significant, and that was that while all the older formations on the northern slopes of the Owl Creek and Rattlesnake Mountains were in a measure intact and comparatively weathered, on the southern or Wind River side the older rocks had been almost entirely swept away, leaving the granite exposed throughout almost the entire extent of the range. This was not done, moreover, since the close of the Wind River epoch, but prior to the laying down of the Wind River sediments, since they are seen in this immediate section to rest directly upon the granite without any trace whatever of the older rocks.

The presumption is therefore that the Wind River country was above water during the existence of the Big Horn Lake, and that the drainage was in another direction - probably to the east-before the present eastern barrier of the Wind River basin was elevated. This would account for the preservation of the older sediments on the Big Horn side of the Owl Creek Mountains, and their remarkable erosion upon the southern or Wind River side.

Sometime subsequent to the close of the Big Horn period a second elevation took place, which cut off the outlet of the waters of the Wind River region, and a second lake was formed on the site of the present Wind River basin. Just how much time elapsed between these changes is difficult to determine, but judging from the relations of their respective faunæ it could not have been very great. 
When the Wind River Lake was finally filled its waters found an outlet to the north, excavating the remarkable gorge now known as the Wind River Cañon. It is through this channel that the drainage has since found an outlet seawards.

\section{SUMMARY.}

The following are the main features of my observations :

I. That the Puerco and Laramie do not underlie the Wahsatch in the Big Horn basin, but the strata rest upon older secondary rocks.

2. That the thickness of the Wahsatch in this basin is about 2500 feet, or considerably less than the 4000 assigned to the same strata in the Vermillion Creek exposures.

3. 'That the Clarke's Fork basin, although geographically separate, is in age and deposition identical with the Big Horn basin.

4. That the Wind River beds are absolutely distinct from the Big Horn Wahsatch, and belong to a succeeding deposition.

\section{VI.-Narrative of Expedition of i89i.}

The expedition into the Big Horn region of Wyoming was outfitted at Red Lodge, Montana, a small mining town at the terminus of the Rock Fork Railroad, which is a side branch of the main line of the Northern Pacific. The outfit consisted of wagon and team, riding horses and other necessary equipments for such a trip. One assistant was employed, Mr. M. L. Jones, of Red Lodge, who not only acted as teamster and cook, but also rendered much assistance in collecting.

Our immediate destination, after leaving Red Lodge, was the extensive exposures lying to the south of the Gray Bull River in the vicinity of its junction with the Big Horn, some hundred and twenty-five miles from the point of starting. After crossing Stinking Water, we turned off the main stage road between Matutau and Red Lodge, and traveled east to the Old Bridge trail. In this region we met with a number of Wahsatch exposures, most of which are entirely barren. The few specimens we secured were very fragmentary. 
Within less than a week we reached the Gray Bull River, but found it impassable on account of high water. While waiting for it to fall we examined the exposures upon the divide between the Gray Bull and Dry Creek to the north, and met with considerable success.

On the south side of the Gray Bull from near its mouth to a point twenty miles up the river are to be found the best exposures of the Big Horn Wahsatch. 'They extend from near the river south for a great distance, and while fossils cannot be said to be abundant at any point, yet careful search through these extensive exposures has resulted in a fairly good collection. It was in this locality therefore that the greater part of the summer was spent.

The examination of the beds within easy reach of the river was not difficult and collecting was comparatively easy, but when we came to extend our field to the more distant bad-lands, we encountered much greater difficulties. Scarcity of water was the greatest obstacle with which we had to contend, and it was only by dint of hard labor and much perseverance that we were able to accomplish the examination of these outlying sections.

Experience of former expeditions into this locality had taught me the necessity of being properly equipped for this emergency, and we accordingly provided ourselves with suitable casks for transporting water on the back of a pack-horse. Our usual method was to establish dry camps in the midst of the bad-lands where one man with a supply of fifteen or twenty gallons of water could subsist for a week or ten days without difficulty. At the expiration of this time he would have completed the examination of the exposures in his immediate vicinity, when his assistant would bring a fresh supply and move his camp into another place. In this way weeks were spent in a search for fossils in regions entirely destitute of water, and it may be said in passing, that some of our best specimens were secured in these places.

Generally the fossils were found washed out of the sediments so that little excavating was necessary. In some instances, however, they were found in the rock. For the most part ordinary methods of collecting were practiced, viz. : gathering up all the pieces and packing them properly for shipment, but the collection of some of the fossils deserves especial mention in view of the somewhat 
novel methods employed. Upon one occasion, while camped alone in the bad-lands, about fifteen miles from the main outfit, I came upon a few teeth which $I$ at once recognized to be of unusual interest. They had washed out of a low sandstone bluff, leaving the point of the lower jaw still remaining. Search as carefully as I would I could not find more than the merest handful of fragments of bone and broken teeth, which were very unsatisfactory indeed. In washing out the fragments that had been deposited upon a level surface some twenty or thirty feet square, I was led to infer that the remaining fragments of perhaps the entire skull were covered up in the loose dirt. Acting upon this I carefully scraped up all the dirt and packed much of it out to the river in sacks on the back of a horse. Later we found a tolerably passable route for our wagon, and hauled it all to the river where we carefully washed it after the manner of the placer miner. In this manner, laborious as it was, we recovered almost the entire upper and lower maxillæ of the rare and hitherto little known genus Palconictis. After cementing the fragments together we find that the entire dentition is present, together with some important parts of the skull. In this way, too, we recovered much of the skeleton of another Creodont (Oxycna lupina), including the carpus and most of the foot bones, which have been hitherto entirely unknown. This simply serves to illustrate the care and energy that are often necessary on the part of the collector if he would meet with even an ordinary measure of success in this region, where anything like complete skeletons are very rare indeed.

Our first side trip was made into the bad-land exposures lying between Gray Bull and Stinking Water in the vicinity of the mouth of the latter stream. In so doing we passed over the old Bridger trail and met with many exposures, most of which were barren. Owing to the extreme scarcity of water, however, and the great distance we would have been compelled to carry it, we did not explore these exposures as thoroughly as we would have done had the circumstances been more favorable.

Our next trip was into the Buffalo basin which, as I have already said, is the upper or western part of the valley of Fifteen Mile Creek. These exposures pertain to a much higher level than those 
of either the Gray Bull or Stinking Water, being probably within 800 or 1000 feet of the top of the entire sedimentary mass. On this account we have kept all collections from this horizon separate from the rest.

Although these beds are mostly barren, we were able to secure a fair collection from them by dint of hard labor. The water and grass were extremely poor at the time of our visit, and it was with great difficulty that we could keep control of our animals. The water was, in fact, but little better than thin alkali mud, and in many instances literally swarmed with animal and vegetable life. Our best finds in these beds were some very good specimens of the peculiar genus Anacodon, together with those of Lemuroids, Rodents and Coryphodons.

Our last trip was into the Wind River basin to the south, and although we had comparatively little time at our disposal, and much traveling to do in order to reach this locality, we successfully accomplished the task, and returned after an absence of twenty days with some important specimens from this horizon to reward us for our efforts. The more or less complete skeletons of Heptodon calciculus and Palcosyops borealis were among the principal finds of this trip.

It was the work of but a few days to get our collections together, pack them properly and return to the point of starting, where we arrived after an absence in the bad-lands of nearly four months. 

